\title{
POWER FROM GLACIERS: THE HYDROPOWER POTENTIAL OF GREENLAND'S GLACIAL WATERS
}

\author{
R. Partl \\ RR - 77- 20 \\ November 1977
}

Research Reports provide the formal record of research conducted by the International Institute for Applied Systems Analysis. They are carefully reviewed before publication and represent, in the Institute's best judgment, competent scientific work. Views or opinions expressed therein, however, do not necessarily reflect those of the National Member Organizations supporting the Institute or of the Institute itself.

International Institute for Applied Systems Analysis

A-2361 Laxenburg, Austria 

Hydropower resources, though limited in quantity, must not be neglected in an exploration of future energy supplies. They are inexhaustible, can be used with high efficiency and good economy, and do not produce pollution or waste problems. The known amount of conventional hydropower resources-estimated by the World Energy Conference--might be significantly expanded by the potential inherent in the waters melting from the ice shield of Greenland.

This paper was prepared by the IIASA Energy Program as part of a more general effort to identify and assess energy sources rich enough to contribute significantly to future global energy demand. It is to be considered a preliminary technical evaluation of the power that could be produced largely based on technology in use today. Some of the problems of the development of this source as well as possibilities of transporting electricity or other products to prospective consumers are addressed. A few of the basic assumptions adopted for this study may still be arbitrary. Therefore, further investigations in situ are needed to test the validity of the findings and conclusions. 
In the southern parts of Greenland, large quantities of water melting every summer from the ice shield $1000 \mathrm{~m}$ above sea level and more, within short distance from the coast, offer favorable conditions for a large-scale hydropower development. General ideas on such a development have been published by several authors. This report tries to go a step further by providing a realistic assessment of available resources, an anlysis of technical problems for the utilization of this resource and its integration into a global energy system, and a preliminary estimate of construction needs and costs.

The estimate of available resources is based on published climatological data for Greenland and other arctic stations, and on a cautious selection of effective solar radiation and albedo values. $210-360 \mathrm{~km}^{3}$ of water is expected to be available during the summer months at an average altitude of $1000 \mathrm{~m}$, corresponding to an energy generation of 460-800 TWh. Continuous generation all-year-round, however, requires storage reservoirs with a total volume of $100-180 \mathrm{~km}^{3}$. In the southwest, numerous large lakes will provide sufficient storage volumes. In the east, storage is a problem, and power generation might be restricted to the summer months.

Some 12 to 15 sites have been identified on the maps where power schemes can be developed with a total installed capacity of 60-120 GW. Hence the estimated hydropower resources of Greenland come close to the 1974 total consumption of electric encrgy in the interconnected grid system of Western Europe which according to the statistics of UCPTE [34] was 724 TWh with a peak load of $118 \mathrm{GW}$.

Technologies for hydropower development are well established and already in progress towards the order of magnitude needed for Greenland. However, methods of collecting water melting from large ice surfaces have still to be studied and tested. The problem of bulk energy transport over great distanees is common to all future global energy supply options, and not specific for the Greenland energy. Carriers envisaged in the report are EHV sea cables and transmission lines on land, hydrogen gas pipelines across sea and land, and tankers for liquid hydrogen or ammonia. Preliminary cost comparisons show each of these carriers to be competitive under specific production and market conditions. The report gives a tentative model for the full development of Greenland's glacier power comprising all these options. 
Construction costs of the power schemes are estimated at 275-320 US. dollars per installed kilowatt, but another $220-430 \mathrm{US} \$ / \mathrm{kW}$ have to be invested in transport facilities such as EHV links or $\mathrm{H}_{2}$ gas pipelines. Liquid $\mathrm{H}_{2}$ as an energy carrier needs lower investments but involves higher energy losses.

The integration of Greenland's glacier power into a global energy system is analyzed according to the criteria adopted for IIASA's Energy Program. No need of fundamental innovation and no serious constraints have been identified for a full development, scheme by scheme, over a construction period of, say, 40 years starting after an initial testing, planning, and design period, of, say, 10 years. A tentative study program is suggested comprising collection of basic scientific data as well as preparatory technical investigations and tests to ascertain the technical feasibility of the development. 


\section{CONTENTS}

\section{Page}

\section{INTRODUCTION}

Precedents

Basic considerations and assumptions

RESERVES AND RESOURCES 3

General conditions 3

Climatic characteristics 4

Geographical criteria $\quad 11$

Estimation of glacier power reserves 13

Available glacier power resources $\quad 15$

$\begin{array}{ll}\text { Critical remarks } & 16\end{array}$

$\begin{array}{ll}\text { TECHNOLOGY } & 16\end{array}$

Introduction $\quad 16$

$\begin{array}{ll}\text { Water collection } & 18\end{array}$

Tunnels and power stations 21

Power application and transfer 23

$\begin{array}{ll}\text { Construction schedule and costs } & 31\end{array}$

EVALUATION AND INTEGRATION INTO A FUTURE GLOBAL ENERGY SYSTEM

General evaluation $\quad 34$

Options for energy transfer trom Greenland

Tentative development model of Greenland's glacier power $\quad 38$

$\begin{array}{ll}\text { Integration into a global energy system } & 39\end{array}$

$\begin{array}{ll}\text { Evaluation of constraints } & 45\end{array}$

FURTHER STEPS TOWARDS A DEVELOPMENT OF THE

GREEN LAND ENERGY 46

Basic information and data collection $\quad 46$

Preparatory technical investigations and tests $\quad 47$

$\begin{array}{lr}\text { REFERENCES } & 49\end{array}$ 

Power from Glaciers: The Hydropower Potential of Greenland's Glacial Waters

\section{INTRODUCTION}

\section{Precedents}

"Greenland is no longer the distant romantic ice region where daring expeditions fight against snowstorms and the danger of freezing to death. Now Greenland has become a testing field of many branches of modern science."

These sentences translated from a book on Greenland today [1] are typical of the trend to conquer this Arctic island for human needs. The U.S. air base of Thule was one step: 7000 laborers worked there for 18 months creating a city for some 8000 inhabitants with all facilities--not only for the airfield but also for a seaport. Then camp Tuto and Camp Century were built on the ice cap and hundreds of technicians settled there for a couple of years to undertake exploratory work. All these stations are at $770 \mathrm{~N}$, an inhospitable latitude compared to the "green pastures" along the coast of Southern Greenland where 1000 years ago Norsemen settled and started "to raise cattle and sheep in large numbers". They did so for about 400 years. Then climatic conditions deteriorated. In the last century, observations revealed a reverse process: an increase in temperature has been influencing ice conditions in and around Greenland; pack ice and ice drift have been reduced and gradually some of the inland glaciers retreated. The annual mean temperatures of the period 1914-1943 are reported to be almost $20^{\circ} \mathrm{C}$ higher than those of the period 1881-1910 [2]. Since 1943, however, temperatures have been declining again.

The enormous mass of ice covering Greenland, combined with steep mountain gradients to the sea, makes hydropower a promising resource, and its development might significantly - although not decisively - contribute to a future energy supply. This is not a new idea. Among others, the Institute of Engineering Research of the Kollbrunner Foundation at Rodio, Switzerland, drew public attention to this energy resource in two of its publications [3] introducing the idea of the Swiss hydrogeologist Stauber of developing "glacier power schemes" in Greeniand to an extent of 2000-8000 TWh per year equalling 250-1000 GW. Technical details of Stauber's idea are protected by patents in several countries including Austria [4]. Notwithstanding the validity and feasibility of many of Stauber's assumptions and methods, the order of magnitude envisaged in [3] seems too optimistic. Even a more modest yield, however, could bring Greenland's hydropower potential to the level of that of entire Europe excluding the USSR 
which according to estimates of the World Energy Conference is some 750 TWh per year $(85 \mathrm{GW})$.

This study aims at estimating in realistic terms the available resources, the appropriate technologies for developing them, the investments and other requirements of such a development, and the integration of Greenland's glacier power into an overall power scenario of the future.

\section{Basic Considerations and Assumptions}

The present status of interaction between precipitation, surface runoff, production of icebergs and their discharge into the sea, and any other component of the hydrological cycle in Greenland is assumed to be in a permanent balance. Provided that solar radiation and temperature conditions do not change fundamentally in the next decades, this balance can be taken as the basis for considerations of the utilization of melting waters from the ice cap. The melting process during the summer months seems to be characterized by abundant melting during daytime - which is reported to produce numerous small ice lakes on the surface - and partial refreezing during night-time although both midnight sun and diffuse radiation maintain a certain minimum melting. The ice lakes are reported to disappear overnight [1].

If we think of using the melting forces of solar radiation to the extent possible we have two ways to intercept this natural microcycle:

- We may catch the melting waters from the ice surface during daytime and collect them in reservoirs of sufficient depth to prevent them freezing again. In addition to surface drainage of large areas by systems of collector canals, we must try to take in as many natural water discharge channels, streams, and creeks as possible, and direct them to our storage reservoirs. By this method we will reduce the surface runoff to the sea as well as iceberg production, and divert melting waters to the power systems.

- We may increase the heat absorption of the ice cap by darkening its surface, by dispersing material with low albedo, to increase the production of melted water. In this case the balance is artifically changed in favor of an increased tapping of the vast reserves bound in the ice mass of Greenland.

The following suppositions must be true if these methods are to be fully effective:

- That the melting water is contained in the topmost strata of the snow and firn cover where it can be caught by an interlinked network of collector canals and transported to the storage reservoirs. 
- That melting water that disappears from the ice surface through fissures and cracks, and flows in deeper horizons of the ice shield (e.g. in intermediate strata of less density) is recovered at the edge of the ice cap where the ice overburden thins out and subsurface streams reappear at a shallow depth where they can be caught by the water ducts of the collector network. If this proves to be practicable, a smaller collector system confined to the border zones is able to drain a much larger area of the ice cap. Ice tunnels acting as subsurface gutters might intensify this process.

- That darkening of the ice surface is technically and economically feasible and sufficiently permanent. Dispersion of dark sand, basalt dust, or any other material from borrow pits on site by special aircraft will be less of a problem than finding the satisfactory balance between the requirements of economy - which means very thin layers of dispersed material - and of stability - which means a dust cover thick enough to prevent it from being easily washed or blown off. Flyash from the big coal-fired power plants of the UK or the USA could be an appropriate material; its transport to Greenland can be done as return load on the tankers needed for transporting liquid hydrogen from the arctic power centers to the consumer regions.

\section{RESERVES AND RESOURCES}

\section{General Conditions}

Greenland's main ice cap covers an area of $1,726,000 \mathrm{~km}^{2}$ [5] and its volume has been estimated at $2,600,000 \mathrm{~km}^{3}$ with a fresh water equivalent of $2,350,000 \mathrm{~km}^{3}$. This is an enormous amount compared with the fresh water reserves in all inland lakes and rivers on earth which total only $125,000 \mathrm{~km}^{3}$. The ice cap is in the shape of a lenticular mass bounded in the east and west by mountain chains, the eastern chain being the higher. The surface of the bedrock descends to sea level north of latitude $670 \mathrm{~N}$ but south of this parallel it rises to a plateau of about $1000 \mathrm{~m}$ elevation with single peaks penetrating the ice cap and forming the so-called Nunataks.

The coincidence of large water volumes with remarkable elevations above sea level at short distances from the shore line in the fjords in favorable for a large-scale hydropower development. However, water will only be available in those parts of the ice cap where climatic conditions allow for an efficient melting process during the summer period. A sufficiently mild maritime climate prevails in the southern part of the island generally south of about $70^{\circ} \mathrm{N}$, and only this area is included in the following estimate of reserves and available resources, based on climatic factors and topographical considerations. 
In this study, the term "ice cap" is defined as the homogeneous ice shield which covers the interior of the island with modest slopes and almost without significant disturbance by cracks and fissures. Excluded from the area of utilization are border zones where crevices and joints would jeopardize the water collectors, the numerous ice streams which protrude with great velocity (up to $30 \mathrm{~m} /$ day) along subglacial valleys to the coast or a fjord, and isolated ice fields or those with no substantial hinterland.

\section{Climatic Characteristics}

\section{Temperature}

The climate of South Greenland is predominantly moderate arctic, and maritime influences reach up to the ice cap due to the many fjords cutting deep into the land mass. The east coast is less favored, being exposed to pack ice and ice drift for longer periods. Angmagssalik, the only important harbor on the east coast situated at $66^{\circ} \mathrm{N}$, is accessible for special arctic vessels only from June through october [1]. The southern end and the west coast, however, are open to every kind of vessel throughout the year up to Holsteinborg at $68^{\circ} \mathrm{N}$.

Monthly records of mean and extreme temperatures of many stations in Greenland have been published in volume 14 of the World Survey of Climatology [5], and by the Meteorological office, London [6]. Monthly mean temperatures of seven selected stations scattered along the coast between Angmagssalik in the east and Umanak in the west are shown in Table 1. With one

Table 1. Monthly and annual mean temperatures in South Greenland.

$\left({ }^{\circ} \mathrm{C}\right)$

\begin{tabular}{|c|c|c|c|c|c|c|c|c|c|c|c|c|c|c|}
\hline station & Latitude & $\mathrm{J}$ & $F$ & M & A & $M$ & $\mathrm{~J}$ & $\mathrm{~J}$ & A & S & o & $\mathrm{N}$ & $\mathrm{D}$ & Year \\
\hline Angmagssalik & $65^{\circ} 37^{\prime}$ & -7 & -7 & -6 & -3 & 2 & 6 & 8 & 7 & 4 & 0 & -3 & -5 & $\mathrm{O}$ \\
\hline Torgilsbu & $60^{\circ} 30^{\prime}$ & -4 & -4 & -3 & 1 & 3 & 6 & 8 & 8 & 6 & 3 & $\mathrm{O}$ & -2 & 2 \\
\hline Nanortalik & $60^{\circ} 08^{\prime}$ & -3 & -3 & -2 & 1 & 4 & 5 & 7 & 7 & 6 & 3 & -1 & -2 & 2 \\
\hline Ivigtut & $61^{\circ} 12^{\prime}$ & -5 & -4 & -3 & 0 & 5 & 8 & 10 & 9 & 6 & 2 & -2 & -4 & 2 \\
\hline Godthaab & $64^{\circ} 11{ }^{\prime}$ & -8 & -7 & -6 & -4 & 2 & 6 & 8 & 7 & 4 & $\mathrm{O}$ & -4 & -6 & -1 \\
\hline Jakobshavn & $6.9^{\circ} 13^{\prime}$ & -13 & -14 & -13 & -8 & 1 & 6 & 8 & 7 & 3 & -4 & -8 & -11 & -4 \\
\hline Umanak & $70^{\circ} 41^{\prime}$ & -13 & -15 & -14 & -10 & -1 & 5 & 8 & 7 & 3 & -2 & -5 & -9 & -4 \\
\hline $\begin{array}{r}\text { Average } \\
\text { stati }\end{array}$ & eve & -8 & -8 & -7 & -3 & 2 & 6 & 8 & 7 & 5 & 0 & -3 & -5 & 0 \\
\hline
\end{tabular}

Data from World Survey of climatology [5]. 
exception (May in Umanak), there are only temperatures above freezing point during the period May through september, while April and october values are partly above and partly below zero. Differences between the coldest and the warmest monthly mean values range from a minimum of $10{ }^{\circ} \mathrm{C}$ at Nanortalik $\left(60^{\circ} \mathrm{N}\right)$ to a maximum of $23 \circ^{\circ} \mathrm{C}$ at Umanak $(710 \mathrm{~N})$. However, deviations from the mean values must be expected. Fortunately they go in both directions: there can be frost in midsummer while occasional temperatures above freezing point have been recorded in every month of the year, even in January and February at nearly all stations.

Along the coast, the melting period is from May through September, with a rather stable distribution from year to year. Relatively high temperatures are also recorded from the edge of the ice cap. It can be assumed that temperature characteristics of the border zones of the ice cap, where melting waters are to be collected, are similar to those of the coast.

\section{Precipitation}

Precipitation is distributed unevenly over the island. Subarctic and maritime influences in the south cause high humidity with annual precipitation up to $2000 \mathrm{~mm}--m o r e$ along some coastal strips--propagating also to the ice cap's border zones, whereas the ice cap itself receives less snow the higher the elevation and the latitude is. The arctic climate of Central and North Greenland is characterized by annual precipitation figures of $200 \mathrm{~mm}$ and less. A year's observation records for a few relevant stations drawn from various sources $[5,6]$ are given in Table 2 .

Table 2. Monthly and annual mean precipitation in South Greenland (mm).

\begin{tabular}{|c|c|c|c|c|c|c|c|c|c|c|c|c|c|c|}
\hline Station & Latitude & $\mathrm{J}$ & $F$ & M & A & M & $\mathrm{J}$ & $\mathrm{J}$ & A & S & 0 & $\mathrm{~N}$ & D & YEAR \\
\hline Angmagssalik & $65^{\circ} 37^{\prime}$ & 58 & 82 & 62 & 53 & 54 & 44 & 35 & 62 & 76 & 90 & 86 & 68 & 770 \\
\hline Torgilsbu & $60^{\circ} 30^{\prime}$ & 151 & 224 & 123 & 119 & 235 & 159 & 71 & 96 & 239 & 192 & 166 & 165 & 1940 \\
\hline Nanortalik & $60^{\circ} 08^{\prime}$ & 64 & 71 & 41 & 59 & 45 & 80 & 53 & 92 & 119 & 125 & 94 & 52 & 895 \\
\hline Ivigtut & $61^{\circ} 12^{\prime}$ & 92 & 129 & 87 & 79 & 89 & 96 & 82 & 97 & 162 & 172 & 146 & 77 & 1308 \\
\hline Godthaab & $64^{\circ} 11$. & 26 & 24 & 18 & 25 & 29 & 46 & 59 & 69 & 84 & 71 & 44 & 20 & 515 \\
\hline $\begin{array}{l}\text { Average } \\
\text { south coast }\end{array}$ & & 78 & 106 & 66 & 67 & 90 & 85 & 60 & 84 & 136 & 130 & 107 & 76 & 1085 \\
\hline Jakobshavn & $69^{\circ} 13^{\prime}$ & 10 & 13 & 14 & 15 & 20 & 19 & 35 & 34 & 41 & 29 & 21 & 18 & 269 \\
\hline Umanak & $70^{\circ} 41^{\prime}$ & 25 & 15 & 12 & 13 & 12 & 12 & 12 & 12 & 21 & 18 & 25 & 24 & 201 \\
\hline Eismitte & $\begin{array}{l}70^{\circ} 54^{\prime} \\
\end{array}$ & 15 & 5 & 8 & 5 & 3 & 2 & 3 & 10 & 8 & 12 & 13 & 25 & 109 \\
\hline
\end{tabular}

Data for coastal stations from World Survey of climatology [5], for Eismitte from Tables of Temperature, Humidity and Precipitation of the Norla [6]. 
Generally there is not much precipitation in July and August which means that sunshine is prevalent during these months - an important finding for the production of melted water. It also means that the predominant source of water available for hydropower generation is melting from large areas of the inland ice while direct discharge from rain during the summer months is negligible.

From isohyetal maps in the Climatologic Atlas of Europe [7] the total precipitation on Greenland south of $71^{\circ} \mathrm{N}$ is estimated at $320 \mathrm{~km}^{3}$ over an area of $860,000 \mathrm{~km}^{2}$, corresponding to an average of $370 \mathrm{~mm}$ per year.

\section{Solar Radiation}

World-wide records on solar radiation have been collected by the University of Wisconsin and published in World Distribution of Solar Radiation [9]. In this register of several hundred observation stations, Greenland is represented with a few single values for Thule; no year-long records for stations in South Greenland are to be found. Stations in Alaska, Canada, and the USSR at latitudes between $60^{\circ}$ and $70^{\circ} \mathrm{N}$ show fairly uniform long-term averages of daily global radiation (direct plus diffuse) and can be applied to Greenland with a high degree of probability. The average of the five stations listed in Table 3 may serve as a basic assumption for the Greenland study, equaling an annual mean of $210 \mathrm{cal} / \mathrm{cm}^{2}$. day or an annual total of $77 \mathrm{kcal} / \mathrm{cm}^{2}$ (see also Figure 1 ).

Table 3. Solar radiation records.

Monthly means of the daily totals of solar radiation (direct + diffuse) on a horizontal surface $\left(\mathrm{cal} / \mathrm{cm}^{2}\right.$. day)

\begin{tabular}{|l|c|cccccccccccc|c|}
\hline \multicolumn{1}{|c|}{ Station } & Latitude & J & F & M & A & M & J & J & A & S & O & N & D & Year \\
\hline $\begin{array}{l}\text { Barrow, } \\
\text { US }\end{array}$ & $71^{\circ} 18^{\prime}$ & 3 & 40 & 191 & 403 & 501 & 547 & 424 & 254 & 115 & 41 & 7 & 0 & 210 \\
$\begin{array}{l}\text { Fairbanks, } \\
\text { US }\end{array}$ & $64^{\circ} 49^{\prime}$ & 19 & 76 & 233 & 385 & 477 & 527 & 444 & 363 & 184 & 86 & 27 & 6 & 236 \\
$\begin{array}{l}\text { Aklavik, } \\
\text { CDN }\end{array}$ & $68^{8} 14^{\prime}$ & 5 & 50 & 202 & 388 & 515 & 528 & 446 & 297 & 156 & 62 & 11 & 1 & 222 \\
$\begin{array}{l}\text { Reykjavik, } \\
\text { IS }\end{array}$ & $64^{\circ}{ }^{\circ}$ & 12 & 56 & 138 & 264 & 396 & 366 & 406 & 298 & 165 & 66 & 18 & 5 & 182 \\
$\begin{array}{l}\text { Arkhangelsk, } \\
\text { Su }\end{array}$ & $64^{\circ} 30^{\prime}$ & 10 & 46 & 172 & 343 & 348 & 462 & 461 & 331 & 141 & 59 & 14 & 5 & 199 \\
\hline $\begin{array}{l}\text { Average of the } \\
\text { five stations }\end{array}$ & 10 & 55 & 185 & 360 & 450 & 480 & 435 & 310 & 150 & 65 & 15 & 5 & 210 \\
\hline
\end{tabular}

From world Distribution of Solar Radiation [9]. 


\section{A. SOLAR RAOIATION}

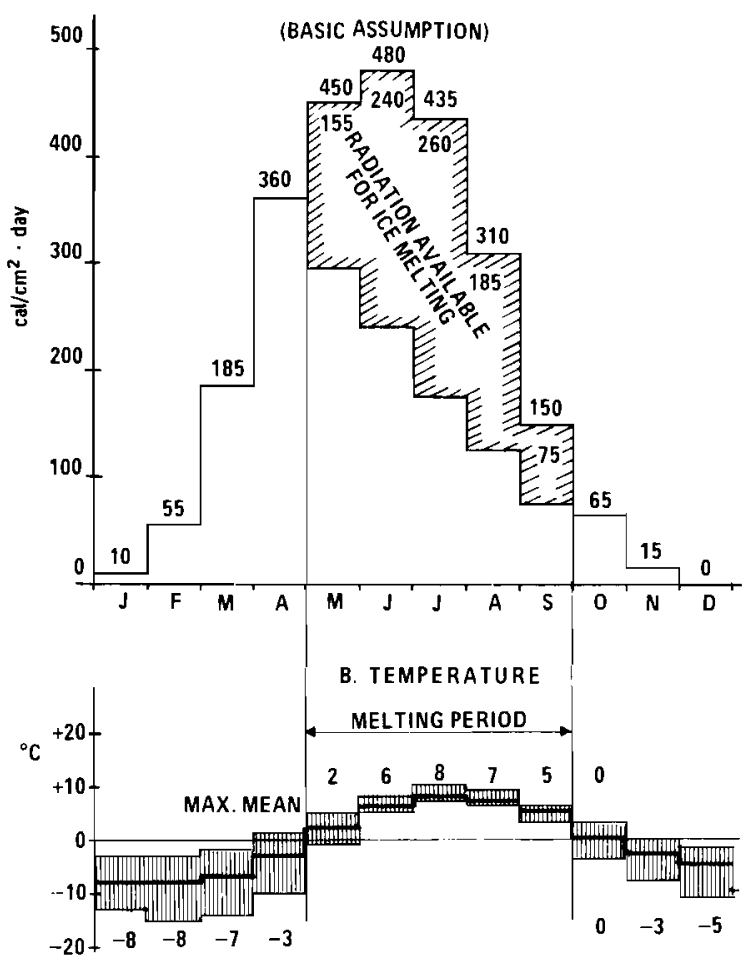

C. PRECIPITATION

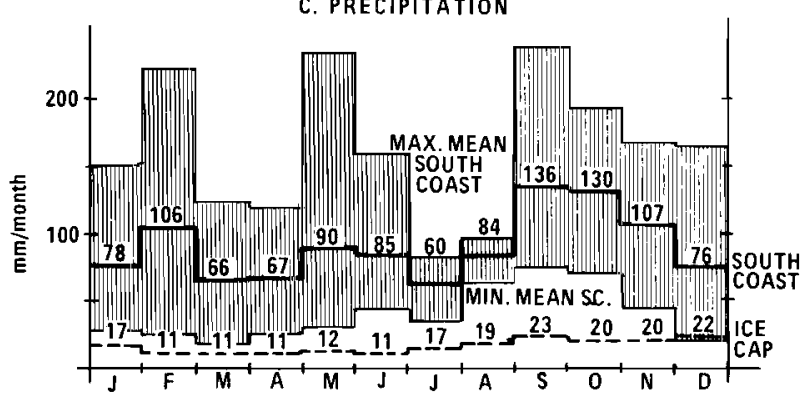

Figure 1. Climatic characteristics of South Greenland. 
Some remarks on the specific insolation conditions of Greenland are to be found in volume 14 of the world survey [5]. Insolation on the ice cap is reported to be rather high due to the relatively high number of sunshine hours and the low water content of the air. Weststation situated on the edge of the ice cap near Alfred Wegener's Peninsula $\left(71^{\circ} 5^{\prime} \mathrm{N}, 51^{\circ} \mathrm{W}, 1000 \mathrm{~m} \mathrm{el.)}\right.$ is said to receive $170 \mathrm{kcal} / \mathrm{cm}^{2} \cdot \mathrm{a}$, and Eismitte $\left(70 \% 54^{\prime} \mathrm{N}\right.$, $40^{\circ} 42^{\prime} \mathrm{W}, 3000 \mathrm{~m} \mathrm{el.)}$ had recorded "a little more". This would equal an annual mean of $465 \mathrm{cal} / \mathrm{cm}^{2}$. day, about 2.2 times the value given in Table 3. This high value seems to have been derived from normal direct beam records and cannot be applied to the almost horizontal surfaces of the glaciers. Relevant mean values for the summer months would go up to $1300 \mathrm{cal} /$ $\mathrm{cm}^{2}$ - day which is much more than the highest values of 700-800 $\mathrm{cal} / \mathrm{cm}^{2}$. day recorded in [9], among others, for some stations in the Antarctic at 2400-2700 m altitude. From these antarctic records one could assume higher than average values for Greenland also. A reasonable alternative is a mean annual insolation of $20 \%$ more than the basic value, i.e. $252 \mathrm{cal}^{2} \mathrm{~cm}^{2}$ - day corresponding to an annual insolation total of $92 \mathrm{kcal} / \mathrm{cm}^{2}$.

Loewe [10] gives indications on the monthly distribution of insolation on Greenland over the year. Applied to the assumption of $92 \mathrm{kcal} / \mathrm{cm}^{2}$. a, this distribution allows assessment of alternative solar radiation values for each month according to column 2 of Table 4 .

Table 4. Assumptions for solar radiation in Greenland.

\begin{tabular}{|c|c|c|c|c|c|c|}
\hline \multirow[t]{2}{*}{ Month } & \multicolumn{2}{|c|}{$\begin{array}{l}\text { Global } \\
\text { radiation }\end{array}$} & \multicolumn{2}{|c|}{$\begin{array}{l}3 \\
\text { Radiation available } \\
\text { for melting }\end{array}$} & \multicolumn{2}{|c|}{$\begin{array}{l}5 \\
\text { Solar energy } \\
\text { input/month } \\
\text { available } \\
\text { for melting }\end{array}$} \\
\hline & $\begin{array}{l}\text { Basic } \\
\quad\left(\mathrm{cal} / \mathrm{cm}^{2}\right.\end{array}$ & $\begin{array}{l}\text { Alt. } \\
\text { - dayl }\end{array}$ & $\begin{array}{l}\text { Basic } \\
\left(\mathrm{cal} / \mathrm{cm}^{2}\right.\end{array}$ & $\begin{array}{c}\text { Alt. } \\
\text { dayl }\end{array}$ & $\begin{array}{c}\text { Basic } \\
\mathrm{kcal} / \mathrm{m}^{2}\end{array}$ & $\begin{array}{c}\text { Alt. } \\
\mathrm{kcal} / \mathrm{m}^{2}\end{array}$ \\
\hline Jan. & 10 & 0 & - & - & - & - \\
\hline Feb. & 55 & 30 & - & - & - & - \\
\hline Mar. & 185 & 110 & - & - & - & - \\
\hline Apr. & 360 & 370 & - & - & - & - \\
\hline May & 450 & 630 & 180 & 250 & 56,000 & 77,000 \\
\hline Jun. & 480 & 700 & 240 & 350 & 72,000 & 105,000 \\
\hline Jul. & 435 & 600 & 260 & 330 & 80,000 & 102,000 \\
\hline Aug. & 310 & 350 & 185 & 210 & 57,000 & 65,000 \\
\hline Sep. & 150 & 150 & 75 & 75 & 22,000 & 22,000 \\
\hline Oct. & 65 & 60 & - & - & - & - \\
\hline Nov. & 15 & 0 & - & - & - & - \\
\hline Dec. & 0 & 0 & - & - & - & - \\
\hline Year & 210 & 252 & . & - & 287,000 & 371,000 \\
\hline
\end{tabular}

Basic assumption: Average of the five arctic stations from Table 3 . Alternative assumption: Basic assumption +208 with distribution according to Loewe $[10]$. 
Even apart from the albedo effects introduced in the next section, not all global radiation will be available for producing water from snow and ice. Firstly, it is expected that melting only occurs in months with average temperatures above zero, i.e. May through September. Gerdel [11] made an estimate of occurrences of melting on the ice cap during the midsummer season June through August, and found that south of $67^{\circ} \mathrm{N}$ considerable melting may be expected even at elevations as high as $2700 \mathrm{~m}$. The number of midsummer days with temperatures above $0{ }^{\circ} \mathrm{C}$ is reported to be reduced from 92 days to 91-92 days at $1000 \mathrm{~m}, 86-90$ days at $1500 \mathrm{~m}, 66-69$ days at $2000 \mathrm{~m}$, and 41 days at $2500 \mathrm{~m}$. Further limitations of efficiency exist:

- A portion, say $10 \%$, of the energy available for melting might be used to heat up the ice from lower temperature levels to $0{ }^{\circ} \mathrm{C}[12]$, and another small percentage is needed to keep the water warm enough for transport, storage and operation.

- Not all melted water is available for runoff; some seeps into deeper layers and refreezes [13].

A cautious assessment is that not more than $50 \%$ of the net radiation during May through september will be effective for melting. With some arbitrary variation of the reduction factors between 40 and $60 \%$ in single months, the effective input of solar radiation is estimated as shown in columns 3 and 4 of Table 4. Columns 5 and 6 show the conversion to the technical units used for further data processing. Radiation input available for the melting process during the summer season ranges from 290,000 to $370,000 \mathrm{kcal} / \mathrm{m}^{2}$.

\section{Heat Absorption and Available Melting Water Volumes}

The albedo of the ice cap of Greenland is estimated to be more than $80 \%$ globally. In the coastal area, however, there are places where during summer months the albedo is even less than 20\%. This is especially pronounced in July and August [5].

Sellers [14] registered specific albedo values for various surface conditions. For this study records have been selected, and the absorption of solar radiation has been used as shown in Table 5:

Table 5 .

\begin{tabular}{|c|c|c|}
\hline Surface & Al bedo & Absorption \\
\hline Fresh snow & $75 \cdots 85 \cdots 95 \%$ & $15 \%$ \\
\hline old snow & $40 \ldots 60 \ldots 70 \%$ & $40 \%$ \\
\hline Ice & $30 \cdots 40 \%$ & $60 \%$ \\
\hline Darkened surface & $5 \cdots 10 \cdots 15$ 웅 & $90 \%$ \\
\hline
\end{tabular}


Further considerations are based on two models:

Model 1 without artificial darkening, assumes that one-third of the ice cap area is covered by fresh snow, old snow, and ice. This is not only an integral over space but also over time. The average absorption of this model is

$$
\frac{1}{3}(0.15+0.40+0.60)=0.38
$$

and efficient heat absorption amounts to

$$
0.38(290,000-370,000)=110,000-140,000 \mathrm{kcal} / \mathrm{m}^{2}
$$

for the whole summer.

Since melting of $1 \mathrm{~m}^{3}$ water from ice requires $80,000 \mathrm{kcal}$, the heat absorbed would result in a melted depth of $1.40-1.75 \mathrm{~m}$ of water. This result fits very well into a statement of Loewe [10] that $1.5 \mathrm{~m}$ of ice is melted during a year at $71^{\circ} \mathrm{N}$ and $1000 \mathrm{~m}$ elevation.

Model 2 considers the possibility of artificial darkening of the snow and ice surface. Given the extensive areas considered for utilization it will never be feasible to cover them with a complete layer of low-albedo material [15]. A cautious assumption is that one-quarter of the total area can be treated this way. The remaining three-quarters is again equally distributed among fresh snow, old snow, and ice. Average absorption of this model is

$$
\frac{1}{4}(0.90+0.15+0.40+0.60)=0.51
$$

and efficient heat absorption

$$
0.51(290,000-370,000)=150,000-190,000 \mathrm{kcal} / \mathrm{m}^{2} \text { for }
$$

the whole summer

sufficient to melt a depth of 1.90-2.40 m of water. Thus darkening of one-quarter of the entire area results in an extra melting of $0.50-0.65 \mathrm{~m}$ of water. 


\section{Geographical Criteria}

Topographic conditions of Greenland south of $72^{\circ} \mathrm{N}$ have been studied in a preliminary manner by using the USAF Operational Navigation Chart issued by the US Aerospace Center, St. Louis, Missouri, ONC sheets $\mathrm{C}-13$ and $\mathrm{D}-16$. These are maps 1:1,000,000 with $1000 \mathrm{ft}(\sim 300 \mathrm{~m})$ contour lines and sufficient terrain characteristics to give overall information on sites suitable for a glacier power development. Figure 2 is a sketch 1:5,000,000 of South Greenland copied from the Times Atlas of the world of 1973 [8], and amended by the border line and contour lines of the ice cap as well as other details from the ONC sheets.

For climatic reasons, considerable melting waters are to be expected only south of about $71^{\circ} \mathrm{N}$, and the study is confined to this area of the island. On the east coast, topographic conditions give a further constraint. South of the Scoresby Sound $\left(70^{\circ} \mathrm{N}\right)$ down to the watkins Fjord $\left(68^{\circ} \mathrm{N}, 32^{\circ} \mathrm{W}\right)$ the edge of the ice cap is mostly at elevations high above the ablation zone, and always too far from sea level for any reasonable development.

Around the Gardiner Lake $\left(68^{\circ} 30^{\circ} \mathrm{N}, 33^{\circ} \mathrm{w}, 850 \mathrm{~m} \mathrm{el.}\right)$ a glacier power scheme seems feasible although conditions do not allow a large-scale development there. More favorable conditions are to be found south of Angmagssalik $\left(66^{\circ} \mathrm{N}\right)$ where the ice cap is a suitable distance from some fjords and has considerable extent. The coastal mountain chain goes up to altitudes of $1000-1300 \mathrm{~m}$. A disadvantage is the lack of natural lakes or other opportunities for storage on rocky ground. Storage reservoirs must be provided on the ice cap itself. In some parts of the southeast, the ice cap protrudes right out to the coast with almost no mountainous border zone between ice and ocean.

More favorable conditions might be found at the southern end of Greenland, if also in minor catchment areas of about $5000 \mathrm{~km}^{2}$ only. Near Narssarssuaq $\left(61031 \cdot \mathrm{N}, 45-46^{\circ} \mathrm{W}\right)$ several natural lakes at elevations of $800-1000 \mathrm{~m}$ offer storage facilities at a distance of not more than $10 \mathrm{~km}$ from the coast of the Bredefjord and its branches.

Suitable conditions continue along the west coast until about $67^{\circ} \mathrm{N}$ at Söndre (Southern) Strömfjord. Steep fjords cut into the land mass and every now and then approach the edge of the ice cap which is generally at an altitude of $800-1000 \mathrm{~m}$. Mountain valleys between the fjords contain a considerable number of smaller and bigger lakes at various elevations. They favor hydropower development in a chain of plants with very short aqueducts making use of the heads between the lakes and finally to the sea.

A specific phenomenon exists north of the Strömfjord between parallels $66^{\circ}$ and $68^{\circ} \mathrm{N}$ : the ONC sheet C-13 shows a 


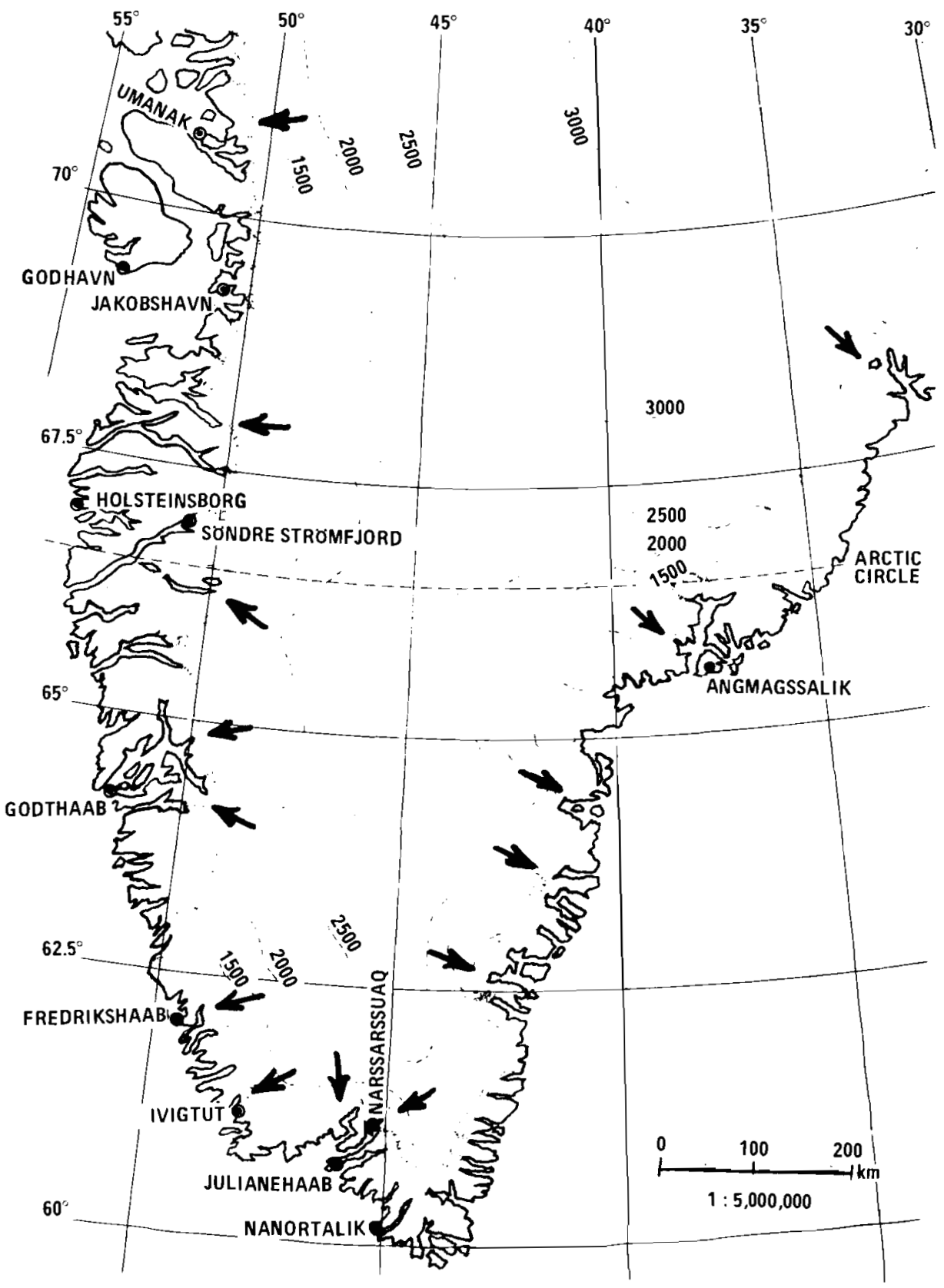

Figure 2. South Grcenland 
large number of ice lakes scattered over the surface of the ice cap at altitudes of 600 to $1800 \mathrm{~m}$, with obviously permanent surface water ducts between each other $\left(66^{\circ} \mathrm{N}\right)$ or as isolated lakes without surface discharge $\left(68^{\circ} \mathrm{N}\right)$. This phenomenon will certainly favor water collection and storage but is partly counteracted by the disadvantage of a gross head of only some $500 \mathrm{~m}$ being available between the edge of the ice and the coast.

North of $68^{\circ} \mathrm{N}$ the ice cap comes close to the shore of the Disko Bay and the Umanak Fjord $\left(71^{\circ} \mathrm{N}\right)$ with but a narrow and low mountain zone fragmented by tremendous ice streams. The Jakobshavn ice stream is reported to be one of the biggest producers of icebergs. Here hydropower development will find a natural limit, or at least it will be hampered by the fragmentation of the catchment areas.

\section{Estimation of Glacier Power Reserves}

Hydroenergy can be made available from those areas of the ice cap where ablation during the summer period is sufficient to produce considerable amounts of water. A schematic cross section through Greenland along the $65^{\circ} \mathrm{N}$ parallel is shown in Figure 3, with glaciation details taken from a report on the International Glaciological Expedition 1957-60 to Greenland [16]. The zone of ablation extends from the edge of the ice cap up to elevations of $2200-2300 \mathrm{~m}$ (7500 ft) and is larger and less inclined along the western slope than in the east.

Benson [17] distinguishes four different glacier zones:

- the dry snow zone with no melting at all;

- the seeping zone with some melting water seeping into the firn and refreezing there;

- the soaking zone where the firn is filled up with melting water and produces runoff; and

- the ablation zone where the snow cover is completely melted off during summer.

From Golubev's theory [13] it becomes evident that only the third and fourth zones have water runoff during the summer months and can be regarded as a glacier power resource. Benson estimates the width of the third zone in Southwest Greenland at about $50 \mathrm{~km}$, and that of the fourth about $100 \mathrm{~km}--$ in very good agreement with the Häfeli sketch reproduced in Figure 3 .

From the ONC sheets the entire area between the edge of the ice cap and the $7500 \mathrm{ft}(2200-2300 \mathrm{~m})$ contour line, from $690 \mathrm{~N}$ in the east to $72^{\circ} \mathrm{N}$ in the west is assessed at roughly 250,000 $\mathrm{km}^{2}$. Under Model 2 conditions (see earlier) the area provides a water yield of $250,000 \mathrm{~km}^{2} \times(1.90-2.40 \mathrm{~m})=475-600 \mathrm{~km}$ per year and over an average gross head of $1000 \mathrm{~m}$ corresponding to 


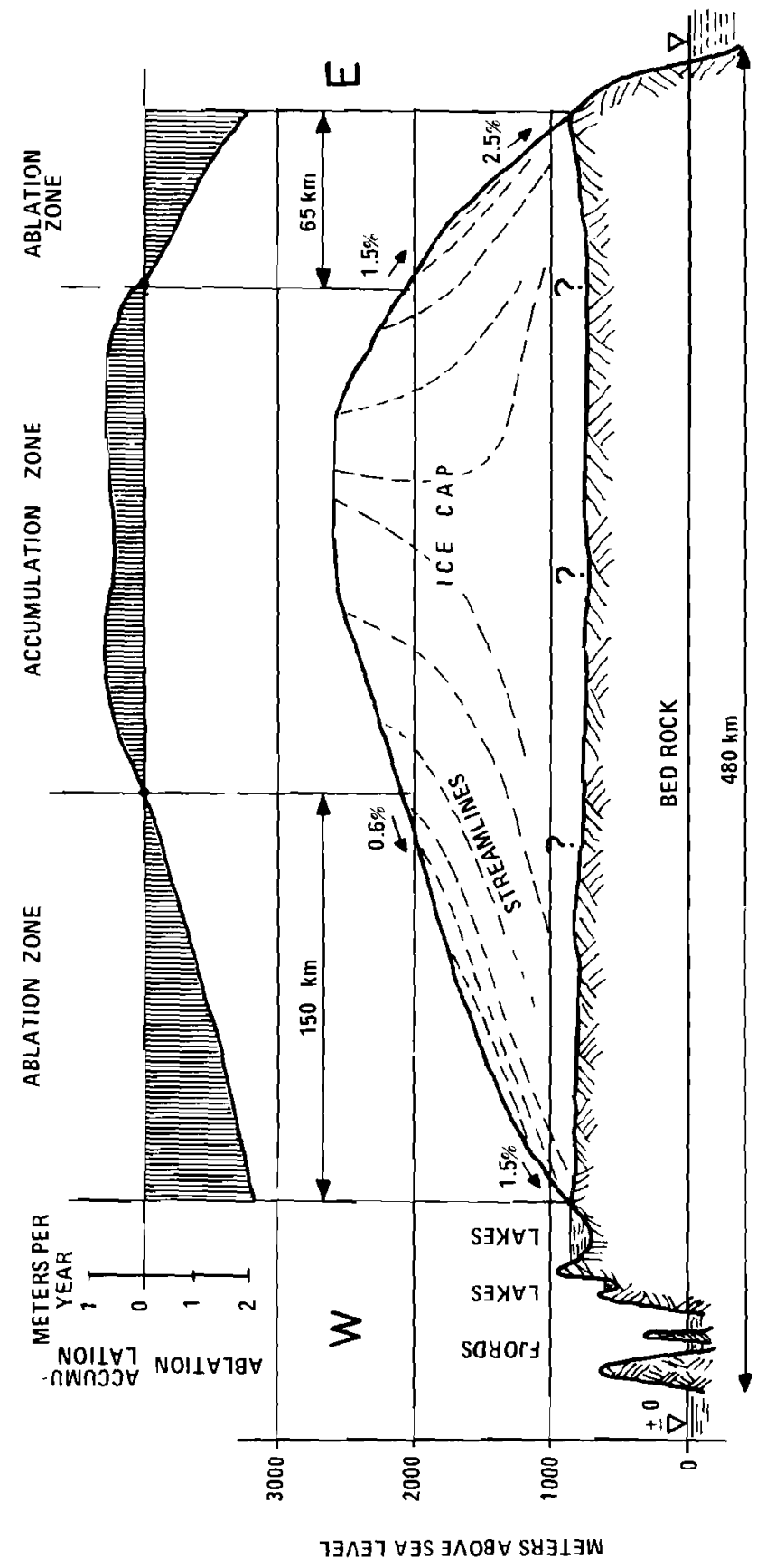

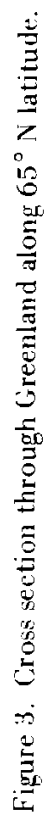


an energy equivalent of $2.2 \mathrm{TWh} / \mathrm{km}^{3}$ of water, this volume is able to generate $\left(475-600 \mathrm{~km}^{3}\right) \times 2.2 \mathrm{TWh} / \mathrm{km}^{3}=1050-1320 \mathrm{TWh}$ equal to a continuous power flow of 120-150 GW. These amounts represent the technically feasible reserves of Greenland's glacier power.

\section{Available Glacier Power Resources}

In a preliminary survey of the ONC sheets, 12-15 sites could be identified where large-scale hydropower schemes might be developed. Some features of these sites are:

\begin{tabular}{|c|c|c|}
\hline Catchment area & $3,500-22,000 \mathrm{~km}^{2}$ & average $10,500 \mathrm{~km}^{2}$; \\
\hline Intake elevation & $300-1700 \mathrm{~m}$ & average $1000 \mathrm{~m}$ \\
\hline $\begin{array}{l}\text { Distance from intake } \\
\text { to shore }\end{array}$ & $5-22 \mathrm{~km}$ & average $11 \mathrm{~km}$; \\
\hline $\begin{array}{l}\text { Available reservoir } \\
\text { area outside ice }\end{array}$ & $0-250 \mathrm{~km}^{2}$ & average $60 \mathrm{~km}^{2}$. \\
\hline
\end{tabular}

Table 6 .

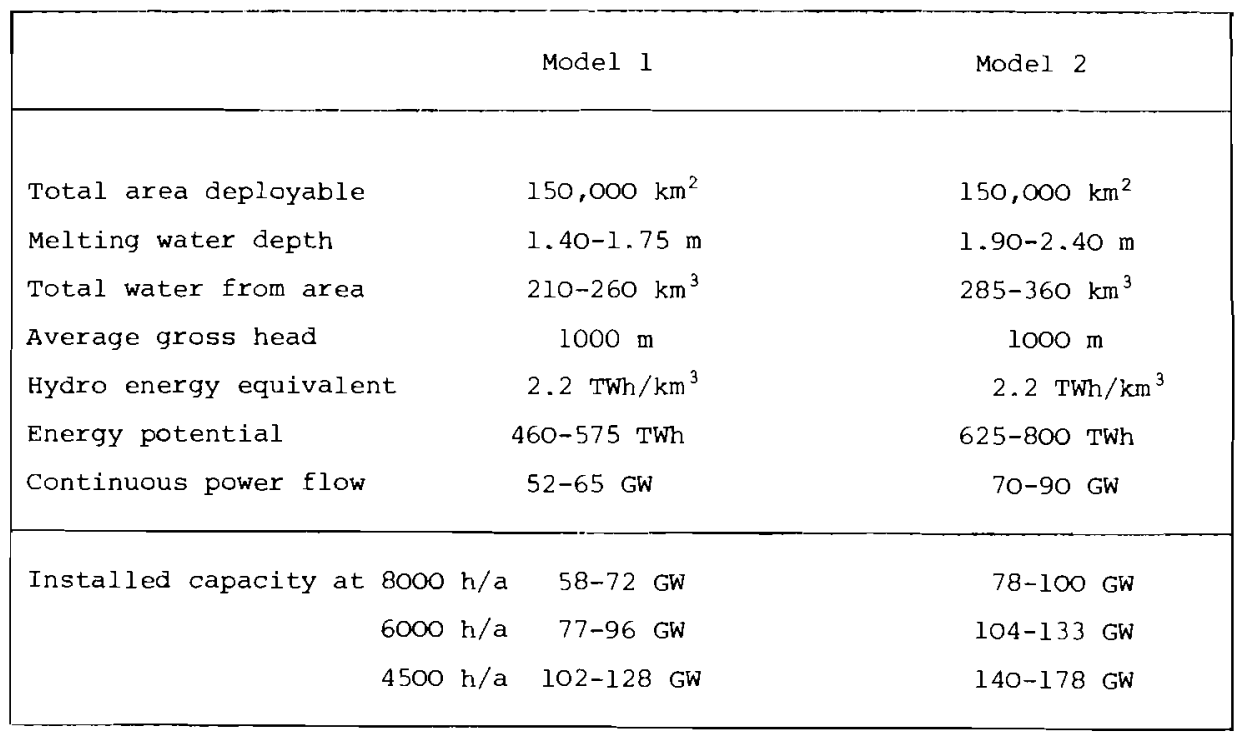




\section{Critical Remarks}

The estimate of available resources gives annual water yields of $210-360 \mathrm{~km}^{3}$. This is approximately in line with the annual precipitation on South Greenland's total surface which is $320 \mathrm{~km}^{3}$ (see earlier). A portion of the precipitation will continue to flow to the sea in surface rivers or ice streams without going through the turbines. Development of glacier power resources, especially under the conditions of Model 2, will cause additional tapping of the ice deposits of the order of perhaps $100-200 \mathrm{~km}^{2}$ a year. This is a negligible amount compared with the total ice volume of $2,600,000 \mathrm{~km}^{3}$.

It is not yet evident whether a permanent system of drainage of large ice areas is technically or economically feasible. There may be doubt whether an assumption of $150,000 \mathrm{~km}^{2}$ as a deployable catchment area is realistic. However, there are reserves not included in the assessment of the water yield: only $50 \%$ of the radiation input has been introduced as being effective, only one-quarter of the area has been adopted in Model 2 for surface darkening, and current precipitation has been neglected. The smaller the area involved, the more intense the utilization will be and the more it will concentrate near the edge of the ice cap where precipitation and insolation are highest and technical obstructions to an efficient development lowest. The assumptions of this study, therefore, appear to be valid and reliable over a wide range of conditions, and have by way of compensation a rather low sensitivity to changes of any one of the parameters.

\section{TECHNOLOGY}

\section{Introduction}

Established, as well as new, technologies will be needed for a large-scale development of Greenland's glacier power resources. Collection of melting waters from large ice areas has not yet been attempted, and optimal methods must be explored. Storage of water will hardly cause problems of technology as long as reservoirs of sufficient size can be embedded in the mountain chains bordering the ice cap; shaping reservoirs in the ice cap itself, however, calls for new ideas. The subsequent transformation of the potential energy of water into kinetic and finally electric energy can rely on well-advanced techniques. Energy transportation from remote generation sites in the arctic to consumption centers in Europe and North America or elsewhere is a problem also with other global power parks envisaged as future energy supply options, and needs no special innovation for Greenland.

The hydropower potential of Europe has been developed since about 1890 and will continue to be, approaching its limit of 750 TWh per year perhaps by the year 2000. During this century 
of evolution the size of individual stations has gradually shifted from the megawatt to the gigawatt level. The Greenland option has to start at the gigawatt or even multiple gigawatt level from the very beginning. However, the unit size of hydropower stations cannot be increased arbitrarily since it depends on conditions offered by nature. Stauber's assumption of a unit size of about $25 \mathrm{GW}$ with a catchment area of $40,000 \mathrm{~km}^{2}$ sounds unrealistic. Although the ice cap extends over a practically infinite area, its border zones - where water intake has to be established - are divided by glacier streams, mountain valleys and fjords which give no scope for unlimited development. The tentative schemes identified on the ONC maps cover an average catchment area of $10,000 \mathrm{~km}^{2}$. This is about 10 to 50 times the catchment area of conventional high-head schemes in Austria, Switzerland or Norway. In the east and southwest of Greenland even larger concentrations seem feasible although the lack of adequate storage opportunities might produce adverse results. Along the west coast, an optimal correlation of ice areas and natural lakes available for storage might split up such a $10,000 \mathrm{~km}^{2}$ unit into several subunits with independent power stations, linked by EHV transmission lines to a central electrolysis plant for conversion into a transportable form of energy.

Essential data for a "5 GW-standard glacier power scheme" have been collected in Table 7. They give the basis for detailed considerations in the following sections on dimensioning the necessary construction components.

Table 7. Basic data of the "5 GW standard glacier power scheme".

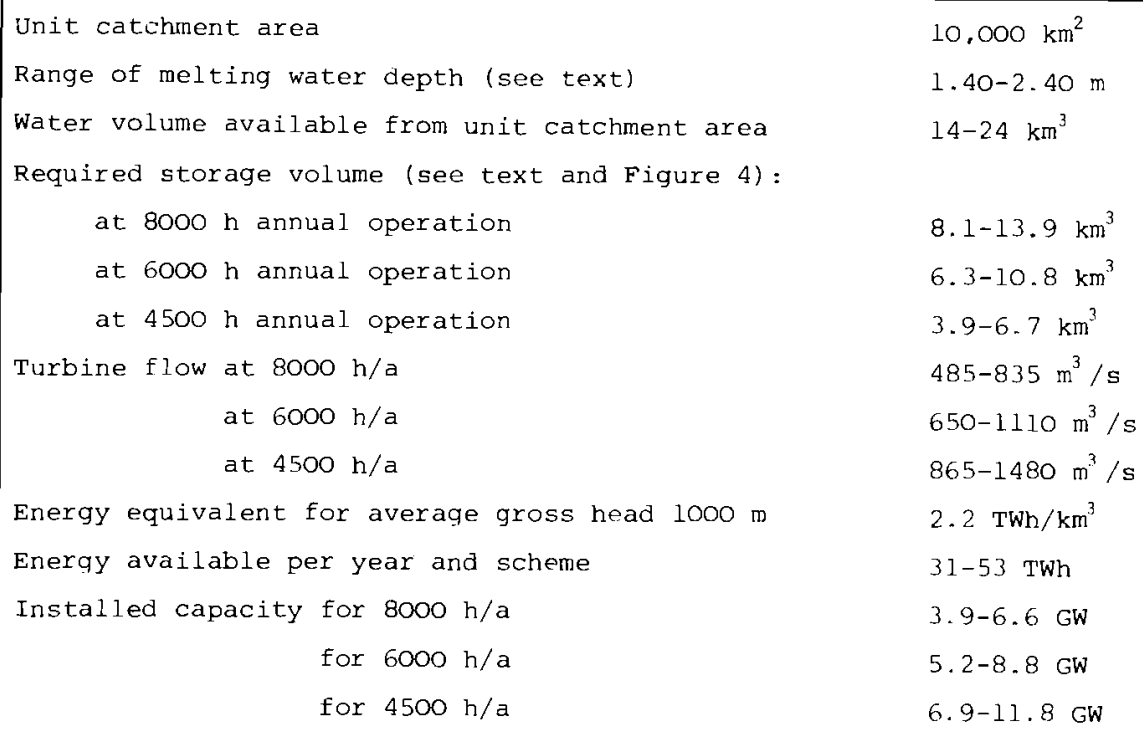

Total hydropower potential of Greenland allows for 15 schemes of the standard size, i.e. 460-800 TWh equivalent to a power flow of 52-90 GW. Total installed capacity might amount to $60-120 \mathrm{GW}$. 


\section{Water Collection}

For the time being we do not dispose of the proved method for collecting water from the surface of large areas. A system of surface canals acting like gutters and as an aqueduct will be the basic requisite. The canals should have parabolic or triangular shape and a minimum depth of a few meters in order to warrant concentration of variable flow in a narrow profile and, together with a gradient not less than $0.5 \%$, sufficient water velocity and turbulence to avoid refreezing of the water. Bulldozers and snowmills might be used to construct the canals in an easy and cheap way. Such equipment has successfully been applied in constructing the ice-shelters of camp Tuto and Camp Century in the Thule district [1]. The Kollbrunner Institute offers other suggestions in its publication no. 27 [18] dealing with ice engineering methods and equipment. Heat-absorbing PVC lining, forced melting by flues heated from motor-exhaust, by electric resistance heating from mobile generators, or by use of the heat of nuclear waste containers could support the excavation.

The canals must form a criss-cross network so that every drop of water has several chances to reach the reservoir. Otherwise a local discontinuity in one canal - caused by ice movements, snowdrift or other hazardous impacts to which the canals are highly exposed - could make the entire system inactive. Ice tunnels of larger section could perhaps expand the canals in lower portions near the edge of the ice cap, and at the same time help to drain subsurface water into the storage reservoir.

It has to be tested whether a few main collectors as suggested by Stauber and patented by him [4] will be sufficient to drain the entire area under consideration. They have to be augmented by the use of natural channels, and by a system of secondary collector trenches like the systems for land irrigation or drainage. Irrigation systems for an area of 1 million hectares $\left(10,000 \mathrm{~km}^{2}\right)$ are not unusual in densely populated zones like India where manpower is easily available and cheap. This is certainly not true in Greenland, but excavation of trenches in ice might be more easily amenable to mechanization and less laborious than in solid soil.

As a very preliminary and tentative estimate, a canal system of $1250 \mathrm{~km}$ length is supposed to suffice for an area of $10,000 \mathrm{~km}^{2}$. During the time of highest solar radiation on a warm July noon, a maximum of $1 \mathrm{~m}^{3} / \mathrm{s}$ discharges from every square kilometer of catchment area while the average discharge on this warm day amounts to $0.45 \mathrm{~m}^{3} / \mathrm{s} \cdot \mathrm{km}^{2}$, and the mean discharge during the entire melting period of 150 days is about $0.18 \mathrm{~m}^{3} / \mathrm{s}$. (For comparison: the peak discharge from $10,000 \mathrm{~km}^{2}$ is equal to the 100 years-frequency flow of the Danube in Vienna experienced in the floods of September 1899 and July 1954. This may suffice to illustrate the order of magnitude inherent in the development of Greenland's glacier power resources.) 
The total ice excavation for a $10,000 \mathrm{~km}^{2}$ collector system feeding a $5 \mathrm{GW}$ standard power scheme is estimated at 50-80 $10^{6} \mathrm{~m}^{3}$. In conventional hydropower, earth movements up to $50 \times 10^{6} \mathrm{~m}^{3} / \mathrm{GW}$ are quite common.

\section{Water Storage}

\section{Storage in Natural Lakes}

Along the west coast, the mountain chains bordering the ice cap carry a large number of natural lakes at various levels up to $1000 \mathrm{~m}$ and more. These lakes are to be expected to give an opportunity of large storage reservoirs with only minor dam structures. Similar conditions exist in Norway and Canada. The Churchill Falls scheme in Labrador with an installed capacity of $5 \mathrm{GW}$ disposes of a live storage volume of $31 \mathrm{~km}^{3}$ which had been created by dams with a total fill volume of $19 \times 10^{6} \mathrm{~m}^{3}$ and a maximum height of $30 \mathrm{~m}$.

The storage volume required for balancing the water yields collected with variable discharge during the short summer period against the continuous operation period of the power station depends on the operation characteristics adopted for power generation. Maximum exploitation of the power facilities and minimum investments are achieved with a year-round operation of, say, $8000 \mathrm{~h}$ at full load. According to the top graph in Figure 4, this operation requires a live storage of $58 \%$ of the annual water yield or in absolute terms $8-14 \mathrm{~km}^{3}$ for each standard scheme.

In the west, lake surfaces of $150-250 \mathrm{~km}^{2}$ are available for each standard scheme. The storage volume mentioned above can be achieved with water level fluctuations of $50-100 \mathrm{~m}$. One-third to one-half of this variation might be effected by damming the natural lake level, the rest by lake tapping. The dams will have modest heights between 20 and $50 \mathrm{~m}$. Fill volumes can be estimated from comparable examples in Canada and Norway. The mean reference ratio of these examples is $0.6 \times 10^{6} \mathrm{~m}^{3} \mathrm{dam}$ fill for each cubic kilometer of live storage. Hence the $5 \mathrm{GW}$ standard scheme in west Greenland may require the very modest amount of $5-10 \times 10^{6} \mathrm{~m}^{3}$ of dam fill.

\section{Reduced Storage Requirements}

Natural reservoirs of equivalent size are not to be found in the south, where lake surfaces of only $30-40 \mathrm{~km}^{2}$ per standard scheme are available, let alone along the east coast, where mountain valleys offering a natural storage facility hardly exist. In order to avoid expensively high dams, operation patterns must be adjusted to the availability of smaller storage volumes, and reservoirs embedded in ice must be considered. 

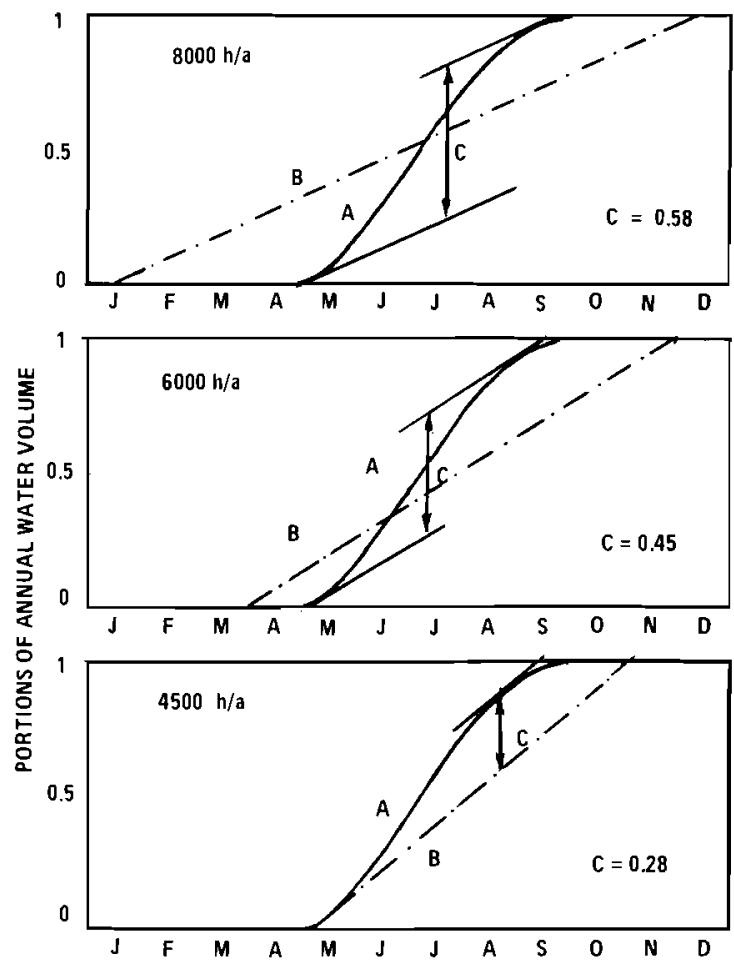

A .. MASS CURVE OF WATER YIELDS (INFLOW)

B... MASS CURVE OF WATER RELEASES

C... REQUIRED STORAGE VOLUME,

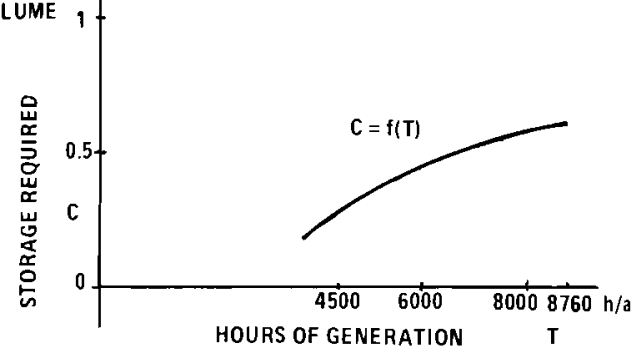

Figure 4. Storage requirements. 
Figure 4 includes two assumptions for intermittent power generation, one with $6000 \mathrm{~h}$ of full load a year, another with $4500 \mathrm{~h}$, i.e. full load periods of 8 or 6 months a year. Relevant storage requirements decrease to $45 \%$ and $28 \%$ respectively or in absolute terms to $6-11 \mathrm{~km}^{3}$ per standard scheme operated $6000 \mathrm{~h}$, and to $4-7 \mathrm{~km}^{3}$ per scheme operated $4500 \mathrm{~h}$. The operation period of $4500 \mathrm{~h}$ (=6 months) fits in with the access conditions of the east coast where owing to pack ice the port of Angmagssalik can be serviced only during May through september [1]. Lack of natural storage facilities and restrictions on energy transportation in the cases of liquid hydrogen or ammonia on tankers have the same impacts on energy generation.

\section{Reservoirs in Ice}

No experience exists on the construction and behavior of ice dams or reservoirs embedded in ice. The technical feasibility of ice as a dam fill material has still to be investigated, and its stability and watertightness to be tested. Provided that the results are satisfactory, the proper method to handle large ice masses poses the next problem. Bulldozers or draglines might be adequate tools to fill an ice dam from parallel borrow trenches. Mobile stripping equipment similar to that used in Germany for open lignite mining, or in Canada for the extraction of tar sands, would combine excavation of large ice cavities with dam filling over its conveyor belt system. A still more efficient method to shape large hollows out of the ice body could be nuclear blasting, provided that contamination is no hazard. Blasting with conventional explosives proved unsuccessful at the air base camps of the Thule district.

The water intake to the power tunnel from the reservoir gives a not less severe problem. Ice does not satisfy the requirements of a safe and stable foundation for intake structures containing gates or valves for controlled water releases, nor for an aqueduct under the pressure of the reservoir level. Hence the reservoir on ice must lean against an abutment or a flank of solid rock of a bordering mountain chain, or against a Nunatak not too far away from that mountain chain. The investigation and selection of adequate sites needs detailed topographical information.

Given the many unknown parameters for constructing reservoirs on ice, a reasonable estimate of amoints of material or other construction requirements is beyond our present knowledge.

\section{Tunnels and Power Stations}

Irrespective of the origin of water, its transport through pressure tunnels and penstocks to the turbines of a conventional power station can rely on well-advanced techniques. Their application in Greenland will hardly cause unusual problems. The 
Kollbrunner publications [3] mention the phenomenon of permafrost and allot certain advantages to it in tunneling in Greenland. These considerations seem refutable for two reasons. Firstly, permafrost will hardly exist in the mountain chains exposed to maritime weather influences and temperatures above freezing point during many months every year. Further, even if tunnels or penstocks should be driven through permafrost zones, the constant flow of water with temperatures above $0{ }^{\circ} \mathrm{C}$ would soon make permafrost disappear in the rock surrounding the water duct.

Tunnels from the final reservoir (the head pond of the power scheme) to the penstock may find favorable conditions in the granitic rock formations of Greenland, similar to those in Norway and Sweden. According to Table 8 , the tunnel of a standard scheme operating $8000 \mathrm{~h}$ a year has to carry $485-835 \mathrm{~m}^{3} / \mathrm{s}$. This requires a cross section of $120-200 \mathrm{~m}^{2}$, which is equal to, or even less than, the area of several existing tunnels in sweden and the USA. For a $4500 \mathrm{~h} /$ per year installation, two parallel tunnels might be cheaper than one super-tunnel. If a reservoir comes close to the shore, the Swedish hydropower type with vertical or steep penstocks directly from the reservoir to a power cavern and a long, pressureless tailrace tunnel to the sea might have technical and economic advantages. Tunnel construction for each standard scheme requires gross average amounts of $1.5 \times 10^{6} \mathrm{~m}^{3}$ rock excavation and $250,000 \mathrm{~m}^{3}$ concrete lining.

Table 8. Energy transport routes Greenland - Europe/North America. (For lengths of sections see Figures 5 and 6. )

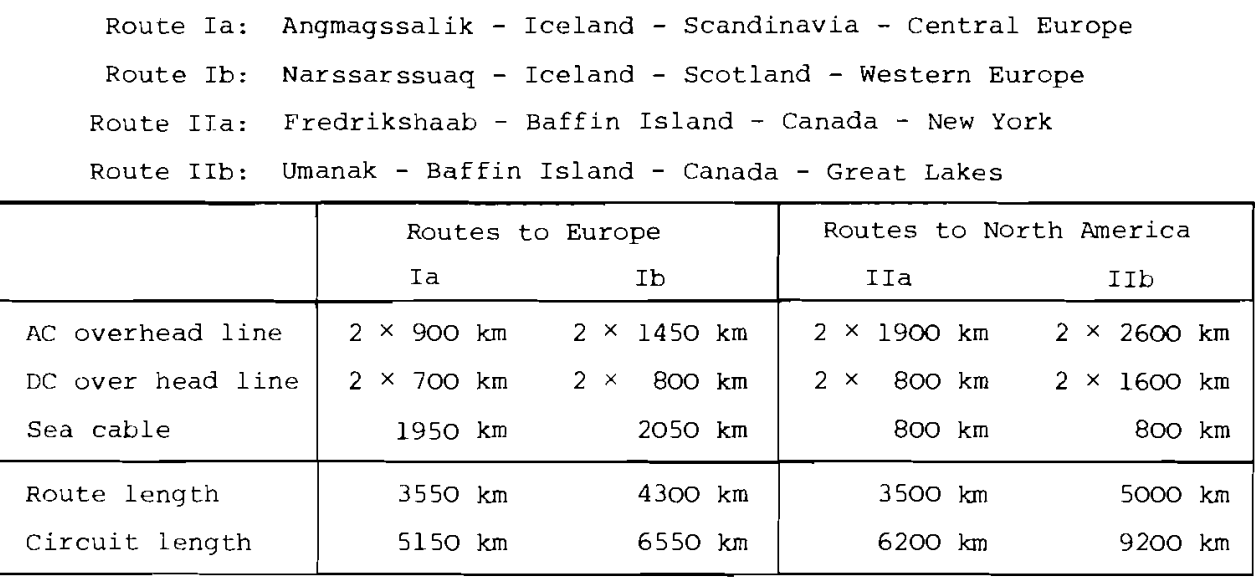

The penstocks have to feed the turbines under an average head of $1000 \mathrm{~m}$ with a total flow of $485-835 \mathrm{~m}^{3} / \mathrm{s}$ equal to the tunnel flow. In the Churchill falls plant in Canada the rated 
discharge is $2000 \mathrm{~m}^{3} / \mathrm{s}$ distributed to 11 penstocks for $186 \mathrm{~m}^{3} / \mathrm{s}$ each under a head of $320 \mathrm{~m}$. In the Malta project of Austria an inclined pressure shaft for $80 \mathrm{~m}^{3} / \mathrm{s}$ under a head of $1000 \mathrm{~m}$ had been designed, and only less favorable geological conditions caused a review of the design and the change to a manifold penstock on the surface. Dimensions required for the Greenland glacier power scheme combine essential features of both existing schemes and should be technically feasible, the more so in view of the designer's freedom to distribute the total flow to an adequate number of parallel penstocks of limited capacity. Average requirements for the penstocks of the standard scheme can be estimated at about $200,000 \mathrm{~m}^{3}$ of rock excavation (probably done by tunnel moles), 50-80,000 $\mathrm{m}^{3}$ of concrete and 40-70,000 t of steel lining.

The standard power station in the basic case of $8000 \mathrm{~h}$ per year operation has an installed capacity of 4-6 GW, a size already existing in Canada and the USSR. Even the jump to $12 \mathrm{GW}$ in case of $4500 \mathrm{~h}$ operation is feasible with regard to the overall outlay. Still open is the type of turbine to be applied. The largest hydropower units of today are of Francis type working under low and medium heads. Extreme prototypes of Francis turbines are those of the Grand Coulee extension in the USA with unit capacities of 600 and $700 \mathrm{MW}$ under a head of $100 \mathrm{~m}$, and Hornberg in the FRG with $250 \mathrm{MW}$ under a head of $630 \mathrm{~m}$. In Norway quite a number of big Francis turbines have been installed with unit capacities between 100 and $160 \mathrm{MW}$ under heads of $400-500 \mathrm{~m}$. Heads of $1000 \mathrm{~m}$ or more are now being utilized by Pelton turbines. Their unit capacity does not exceed $70 \mathrm{MW}$ with a rated flow of only $10 \mathrm{~m}^{3} / \mathrm{s}$. For the Greenland glacial power development, either a modified turbine type with both high head and high flow has to be developed, or a one-step development has to be avoided. The lakes along the west coast offer good opportunities to divide the power scheme into two or more subsequent steps with not more than $500 \mathrm{~m}$ individual head. This allows the stations to be equipped with conventional Francis turbines within the range of present technology.

The generator type has to be selected in view of the power application or conversion. AC is the dominating system of electricity supply and powerful generators of this system have been installed all over the world. For Greenland power schemes closely linked to a large electrolysis plant producing hydrogen or ammonia, DC generation might have advantages. In this preliminary study, the final decision cannot be anticipated, but will have no significant influence on technical or investment considerations. Construction and equipment requirements of the $5 \mathrm{GW}$ standard power station may amount to $100,000 \mathrm{~m}^{3}$ of concrete and 100-150,000 $t$ of steel including machinery.

\section{Power Application and Transfer}

Only a small portion of the energy from the glaciers will be used in Greenland for domestic and industrial purposes. The 
abundant power supply may stimulate processing of natural resources known in Greenland such as iron ore, various non-ferrous metals, uranium and thorium [1]. Demand for processing local resources, however, may not exceed $5 \%$ of the energy produced in the glacier power schemes. The bulk of energy will be available for the supply of consumer centers in Europe and North America.

Options for energy transportation from Greenland to prospective consumer regions, or for large-scale application in Greenland are indicated in the following paragraphs.

\section{Conventional Transmission Systems}

Figures 5 and 6 give a preliminary selection of routes for connecting energy production centers in Greenland with consumer centers in Europe and Northern America. In tracing the routes, attention has been paid to minimizing ocean crossings and making best use of islands and natural rises of the ocean bed, in order to find practicable water depths and as many intermission points as possible. These points subdivide the long transmission lines into pieces of not more than $600 \mathrm{~km}$ in order to secure their stability by adequate technical measures and installations.

Transmission to Western Europe is handicapped by a considerably larger portion of open sea: the total distance of some $4000 \mathrm{~km}$ is almost equally distributed between sea and land. Energy supplies to North America are favored not only by much shorter distances across the ocean west of Greenland but also by the fact that the transmission lines on land pass through wide areas of barren land where the right of way can be obtained much more easily than on European territory. Distances to New York and Chicago are 3500 and $5000 \mathrm{~km}$ respectively. The large hydropower schemes on the Churchill, Manicouagan, Saguenay, and St. Lawrence rivers are valuable points of support to the transmission line stability.

The selection of the most suitable transmission system depends on more in-depth studies anticipating future trends. Comments on conventional systems are:

- AC transmission lines are to be preferred for connecting single power stations to a central feed point into the transmission link over the sea, and for the final portions of the line where junction to national and regional networks must be possible. The long-distance link could be a $1100 \mathrm{kV}$ line with bundled conductors with a capacity of $5 \mathrm{GW}$ per circuit. For sea cables, however, $A C$ is less suitable given the present status of technology. The Swiss publications on Greenland's glacier power [3] suggest a $1140 \mathrm{kV}$ three-phase transocean link consisting of three conductor cables with longitudinal and shunt compensation by synchronous motors. 


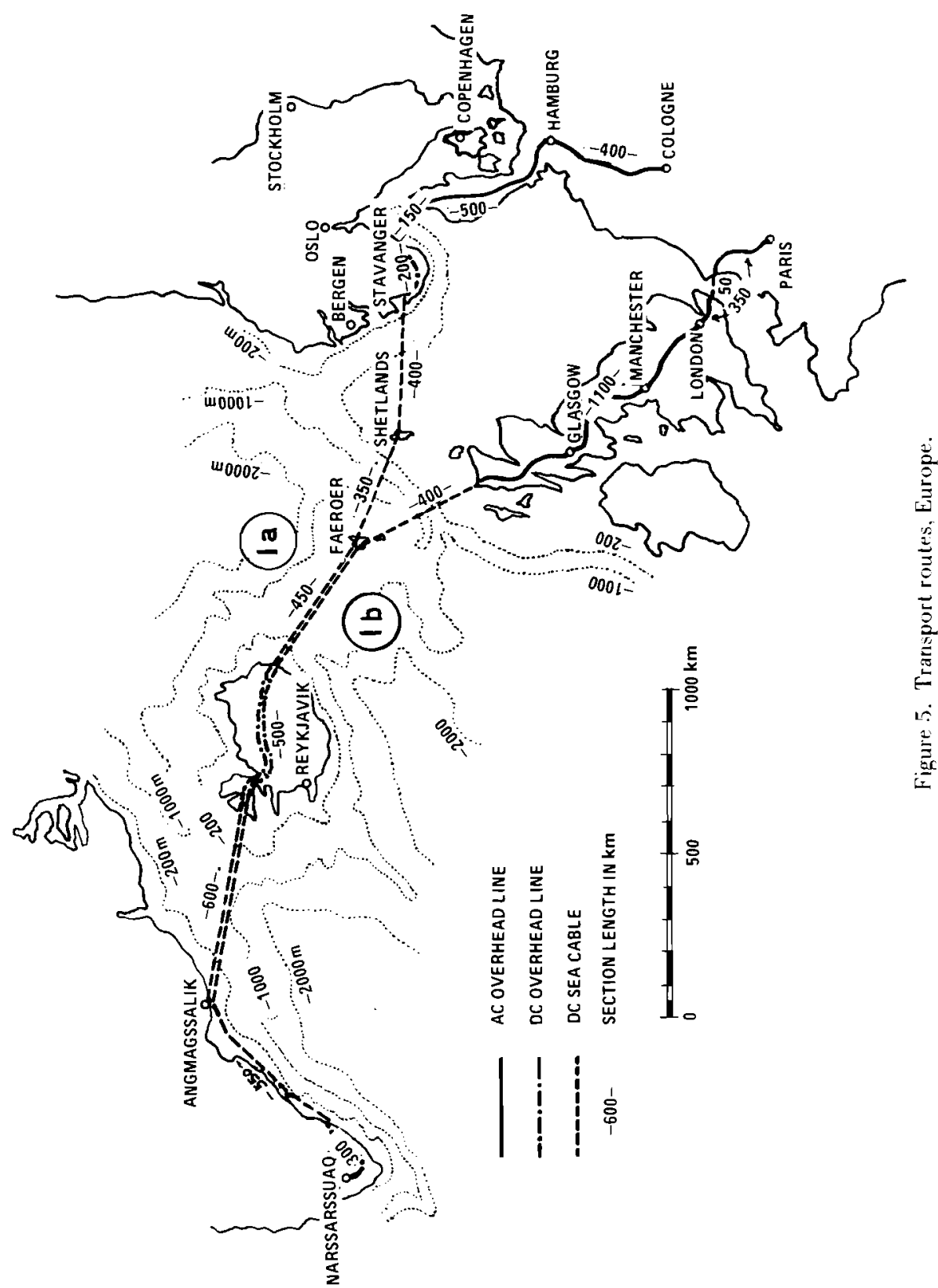




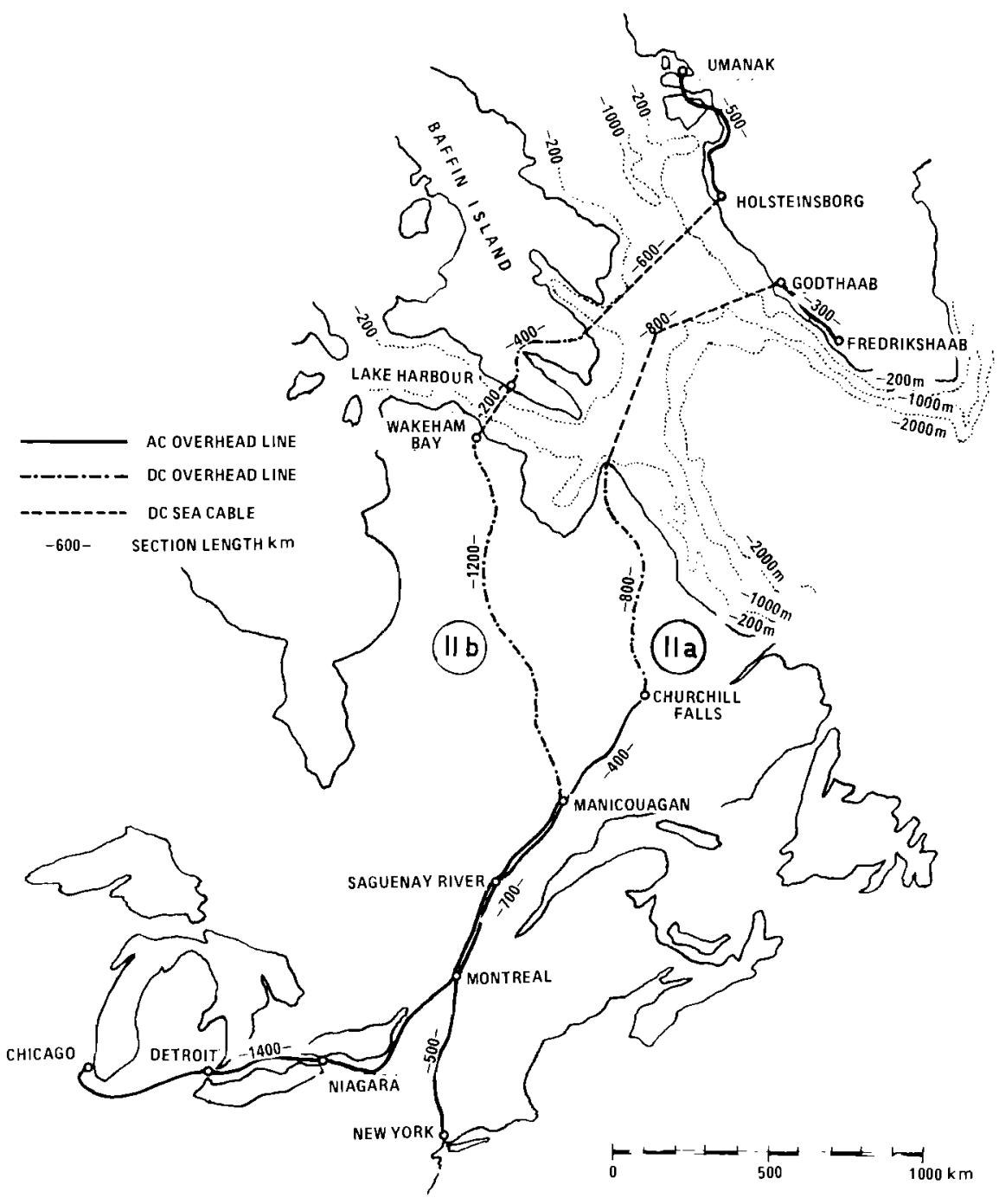

Figure 6. Transport roules, North America. 
- DC is the best system for sea cables. Existing prototypes operate under voltages up to $500 \mathrm{kV}$. A transport capacity of 10-15 GW would be warranted by $750 \mathrm{kV}$ oil cables or by $400 \mathrm{kV}$ super-conductive cables [19]. Both are actually studied in EHV laboratories while $1000 \mathrm{kV}$ cables are still regarded as utopian. On land, $\pm 500- \pm 750 \mathrm{kV}$ DC overhead lines have already been built, e.g. for the $+500 \mathrm{kV}$ transmission line of $1700 \mathrm{~km}$ between the Inga power scheme and the Shaba mine district in zaire [20]. This line consists of two circuits with bundled conducors of three $750 \mathrm{~mm}^{2}$ steel-reinforced aluminum wires each, supported by some 8500 towers. If $750 \mathrm{kV}$ sea cables become feasible, a transport link combining them with $+750 \mathrm{kV}$ DC-overhead lines might be the most convenient connection between the initial AC-DC converters in Greenland and the DC-AC converters in Denmark, Scotland, and Canada where supply into the consumer networks will start. DC lines need less conductors per circuit than AC lines (two against three for overhead lines, one against three for sea cables with the sea as return duct) and have lower transport losses in conductors of equal cross section. These advantages might make up for the additional converter expenses.

EHV cables are inclined to have more faults and outages than overhead lines. In order to bring the transport safety of the cable link to the safety level of the double-circuit overhead line, a spare cable for each route has to be installed in addition to the active ones. Along the selected routes, the sea is generally less than $600 \mathrm{~m}$ deep, where cables can be laid on the bottom. If channels of greater depth have to be crossed, technology has still to be found for cable-laying, or suspended cables have to be developed. They have to float at such a depth below sea level that wave action or icebergs cannot destroy them.

For transporting approximately $10 \mathrm{GW}$ over each of the four routes described in Table 8 , requirements for overhead lines with bundles of two conductors, and sea cables of relevant capacity and safety are summarized in Table 9.

Table 9 .

\begin{tabular}{|c|c|c|c|c|}
\hline Route & Ia & Ib & IIa & IIb \\
\hline AC double circuit overhead & & & & \\
\hline route length $\quad(\mathrm{km})$ & 900 & 1450 & 1900 & 2600 \\
\hline wire $=$ route $\times 6 \times 2 \quad(\mathrm{~km})$ & 10800 & 17400 & 22800 & 31200 \\
\hline DC double circuit overhead & & & & \\
\hline route length $\quad(\mathrm{km})$ & 700 & 800 & 800 & 1600 \\
\hline wire $=$ route $\times 4 \times 2$ & 5600 & 6400 & 6400 & 12800 \\
\hline DC sea cable & & & & \\
\hline route length & 1950 & 2050 & 800 & 800 \\
\hline cable $=$ route $\times 2$ & 3900 & 4100 & 1600 & 1600 \\
\hline Material of overhead lines & & & & \\
\hline Aluminum $\quad(1000 t)$ & 30 & 44 & 54 & 80 \\
\hline Steel, wires & 11 & 16 & 20 & 30 \\
\hline Steel, towers & 72 & 102 & 122 & 190 \\
\hline
\end{tabular}




\section{Non-Conventional Energy Transfer}

The most promising non-conventional economic mode of transport of large amounts of energy is to use hyarogen as energy carrier. It can easily be stored, transported, and reconverted into mechanical, electrical, or thermal energy.

With technology improving in the future, $\mathrm{H}_{2}$ electrolysis is expected to convert $3.3 \mathrm{kWh}$ into $1 \mathrm{Nm}^{3}$ of $\mathrm{H}_{2}$ in a process requiring $0.8 \mathrm{~kg}$ of water [21,22]. (For comparison: hydroelectric generation of $3.3 \mathrm{kWh}$ under a head of $1000 \mathrm{~m}$ requires $1500 \mathrm{~kg}$ of water. Thus $1 / 2000$ of the turbine discharge had to go into $\mathrm{H}_{2}-$ electrolysis.) Allowing $10 \%$ of the energy generated annually in a standard glacier power scheme (31-53 TWh--see Table 7), for local consumption and conversion losses, the remaining 28-48 TWh gives an annual production of $8.5-14.5 \times 10^{9} \mathrm{Nm}^{3}$ or $0.75-1.3 \mathrm{Mt}$ of $\mathrm{H}_{2}$ gas. Transport to the consumer centers in Europe and North America can be effected in two ways:

- Transport of $\mathrm{H}_{2}$ gas through pipelines along the routes selected for electric transmission over distances of $3500-5000 \mathrm{~km}$. Transport flow per standard scheme during $8000 \mathrm{~h}$ is $300-500 \mathrm{Nm}^{3} / \mathrm{s}$, and with an initial pressure of 65 bar, pipe diameters of $0.7-0.9 \mathrm{~m}$ on land or a bunde of pipes with equivalent cross section across the sea are needed. Pressure must be maintained by relay compressors every 500-1000 km [23]. Total compressor power for a $4000 \mathrm{~km}$ pipeline is 100-140 MW, and energy consumption during $8000 \mathrm{~h}$ amounts to $800-1100 \mathrm{GWh}--3 \%$ of the transported energy. Pipelines in shallow water are already being used for oil transportation from off-shore wells where the bottom is less than $200 \mathrm{~m}$ below sea level. A trunk line between Tunis and Italy has been planned to reach water depths of $650 \mathrm{~m}$, and a maximum depth of $360 \mathrm{~m}$ has been reached by a pipeline crossing the Strait of Messine [24]. For pipelines crossing channels of $1000 \mathrm{~m}$ and more depth we face the problem already mentioned for sea cables: pipes laid on the sea bottom may hardly be recovered in case of faults, and for floating pipes an adequate technology has still to be found and tested. Pipeline weights for a trunk line carrying the equivalent of $5 \mathrm{GW}$ over each of the four routes, with $50 \%$ weight addition for transocean lengths, are

$$
\begin{aligned}
& 0.76-1.21 \times 10^{6} \mathrm{Mt} \text { of steel for route Ia } \\
& 0.89-1.43 \times 10^{6} \mathrm{Mt} \text { of steel for route Ib } \\
& 0.66-1.05 \times 10^{6} \mathrm{Mt} \text { of steel for route IIa } \\
& 0.91-1.46 \times 10^{6} \mathrm{Mt} \text { of steel for route IIb. }
\end{aligned}
$$

This is about ten to twenty times the steel requirements of an electric transmission system of the same capacity. 
- By liquefaction, the volume of hydrogen is reduced to $1 / 800$ of the gas volume, the density of liquid $\mathrm{H}_{2}$ being about $70 \mathrm{~kg} / \mathrm{m}^{3}$ [21]. With present technology and plant size, the liquefaction process absorbs $27 \%$ of the energy input [25]. In the future, advanced large-scale plants might be operated with not more than $15 \%$ energy loss. Liquid hydrogen can be transported to ports in Europe or North America, and even to ports further from Greenland, by special tankers. For a $5 \mathrm{GW}$ standard scheme, the annual transport weight of liquid $\mathrm{H}_{2}$ including containers will not exceed 1-2 Mt. Two tankers of 50-100,000 t loading capacity each could service a standard power scheme of East Greenland with 10 hauls a year during the ice-free summer and fall months.

\section{Transportation Losses of the Various Transportation Modes}

EHV transmission will have to be managed in such a way that transportation losses do not exceed $10 \%$. Loss estimates in hydrogen transportation are less simple. Conversion of electric energy into $\mathrm{H}_{2}$ is expected to develop to an overall efficiency of almost $100 \%$, and an assumption of $95 \%$ efficiency might be assumed [22]. Transportation losses of the pipelines consist of the energy consumed by the compressors. Liquid hydrogen requires higher conversion losses while propulsion energy of the tankers including the empty back-haul constitutes a transportation loss of less than $1 \%$ of the transported energy. Reconversion of $\mathrm{H}_{2}-$-gas or liquid--into electric energy in conventional thermal power stations or gas turbines should be precluded in view of the low efficiency. Reconversion is justified only if advancing technology allows for large-scale application of fuel cells with an efficiency of at least $70 \%$ [27], or of hot-shot gas turbines as developed by General Electric [26].

The breakdown in Table 10 allows the energy flow and losses from the glacier power station in Greenland to the gross markets in Europe and North America for each mode of transport to be traced (distribution in the market region excluded).

\section{Large-scale Energy Use on Greenland?}

In addition to minor energy supplies to domestic industries processing yet unknown natural resources of Greenland, establishment of energy-intensive industries on adequate coast sites could be envisaged. Three options have been considered, namely production of methane, ammonia, and aluminum.

- Production of methane or another synthetic fuel has to be excluded since Greenland geologically belongs to the Caledonian shield which is known to be poor, if not 
empty, of coal. If coal from North America or the British Isles were to be used, it might be more economic to transport $\mathrm{H}_{2}$ from Greenland to the mining area than coal to Greenland.

Table 10. Predicted yearly energy flow and losses.

\begin{tabular}{|c|c|c|c|c|}
\hline Transport by: & & EHV & $\mathrm{H}_{2}$ gas & Liquid $\mathrm{H}_{2}$ \\
\hline Energy generated & $(T W h)$ & $31-53$ & $31-53$ & $31-53$ \\
\hline Supply to Greenland & (8) & 5 & 5 & 5 \\
\hline Energy for export & $(\mathrm{TWh})$ & $29.4-50.4$ & $29.4-50.4$ & $29.4-50.4$ \\
\hline Conversion loss & (\$) & 5 & 5 & 15 \\
\hline $\begin{array}{l}\text { Energy converted for } \\
\text { transport }\end{array}$ & (TWh) & $27.9-47.9$ & $27.9-47.9$ & $25.0-42.8$ \\
\hline Transport loss & (8) & 10 & 3 & 1 \\
\hline $\begin{array}{l}\text { Energy arriving in } \\
\text { consumer region }\end{array}$ & $(\mathrm{TWh})$ & $25.1-43.1$ & $27.0-46.5$ & $24.7-42.3$ \\
\hline $\begin{array}{l}\text { Conversion loss, } \\
\text { electric use }\left(\mathrm{H}_{2}\right. \\
\text { via fuel cells })^{2}\end{array}$ & $(8)$ & - & 30 & 30 \\
\hline $\begin{array}{l}\text { Electric energy } \\
\text { available }\end{array}$ & (TWh) & $25-43$ & $19-33$ & $17-30$ \\
\hline Total loss & (8) & 19 & 38 & 44 \\
\hline $\begin{array}{l}\text { Conversion loss, } \\
\text { thermal use }\end{array}$ & $(8)$ & 5 & 5 & 5 \\
\hline Thermal energy & (TWh) & $24-41$ & $26-45$ & $24-40$ \\
\hline available & $\left(10^{6} \mathrm{Gcal}\right)$ & $21-35$ & $22-39$ & $21-34$ \\
\hline Total loss & (8) & 23 & 16 & 24 \\
\hline
\end{tabular}

- Production of ammonia as an energy carrier or a raw product for the fertilizer industry is another option since cheap energy, water, and air are available in Greenland. Although the use of anmonia as an energy carrier seems not well accepted [28], the world market's capacity of $80 \mathrm{Mt}$ of ammonia per year is increasing by $10 \%$ p.a. A Greenland standard scheme of 5 GW could produce 5-6 Mt of ammonia per year to supply the market. However, the fertilizer industry appears to have free capacities in some regions, and ammonia production is a favored goal of national development in most of the developing countries. 
- Production of aluminum seems most promising within limits dictated by the market. Long-distance transportation of bauxite is not new: Australian bauxite is being used in the large aluminum factories of the US and Canadian Pacific coast. Considerable quantities of bauxite will in future be marketed by Brazil and equatorial Guinea [29], both regions being located acceptably near Greenland. With a consumption of $16 \mathrm{kWh} / \mathrm{kg}$ aluminum and the low generation cost of the glacier power, aluminum production on Greenland would have energy costs of 75-100 US-\$/ton which would more than compensate for higher transport charges of the raw material and the final product. The price of Greenland aluminum is expected to be 600-700 \$/t--competitive with the output of existing plants with higher energy costs. Limits will be posed by the quantities of bauxite available from the two expanding suppliers mentioned: they will hardly exceed $25 \mathrm{Mt}$ a year, equivalent to some $5 \mathrm{Mt}$ of aluminum, and this production would absorb 80 TW--10-20\% of the Greenland energy.

\section{Construction Schedule and Costs}

\section{Construction Schedule}

Development of Greenland's glacier power resources calls for thorough preparatory investigations and studies, surveying and mapping, collection of hydro-meteorological data, test programs, etc., for which a period of 5 years (say 1980-85) is a minimum. Another 5-year period (1985-90) must be spent on development planning and design, along with preparatory field work such as access, housing and supply facilities, airfields, ports, cableways, and other traffic facilities. Construction of the first power scheme should be started on the west coast where conditions are more favorable than in the east, and must not be scheduled earlier than 1990. Construction of each power scheme may take 5 to 6 years. From experience in implementing the first scheme, construction of two schemes at a time with 2-3 years' overlapping seems feasible. This will result in a continuous construction period of 40-50 years $(1990-2030 / 40)$ for a total of 15 schemes.

\section{Cost of Power Schemes}

The main construction requirements and costs of a standard power scheme are roughly estimated as follows:

Site installation $200-300 \mathrm{M \phi}$

Collectors: $50-80 \times 10^{6} \mathrm{~m}^{3}$ at $2-2.5 \$ / \mathrm{m}^{3} \quad 100-200$

Reservoir dams: $5-10 \times 10^{6} \mathrm{~m}^{3}$ at $10-15 \$ / \mathrm{m}^{3} \quad 50-150$ 


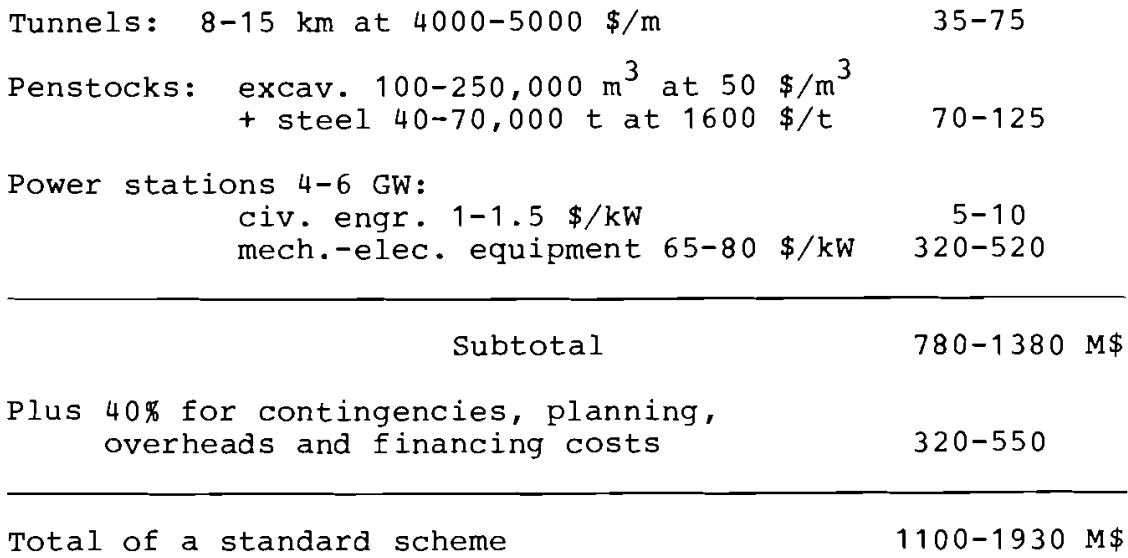

Specific construction costs per power and energy units amount to 275-320 US- $\$ / \mathrm{kW}$ installed, or 3.5-4 cents/kWh of annual energy output, both rather low values which, however, have been approximately achieved in some recent canadian power developments. Owing to the high maintenance and salary costs under the specific difficulties in the ice region, generation costs might be adopted at 12-15\% of the construction costs instead of the $10 \%$ rate under normal conditions of hydropower stations. Hence generation costs in Greenland might be expected at $4.5-6 \mathrm{mills} / \mathrm{kWh}$.

\section{Cost of Energy Transportation--Electric Transmission}

Each EHV standard system carrying $10 \mathrm{GW}$ (80 TWh per year) is able to transfer the energy generated by two standard power stations. Construction requirements and costs of an EHV system along each of the four transmission routes to Europe or North America are presented in Table 11. The estimate of cable costs is based on the expectation that production of large quantities of EHV sea cables over a period of 40 years will decrease unit costs far below the present price level to about 4 times the overhead line price now valid for normal 110 and $220 \mathrm{kV}$ systems. Unit prices are related to the route length and refer to doublecircuit overhead lines and double sea cables.

Specific investment increments for EHV transmission are $310-430 \$ / \mathrm{kW}$ or $4-5.5 \mathrm{ct} / \mathrm{kWh}$ for Europe, and $220-300 \$ / \mathrm{kW}$ or $2.5-4 \mathrm{ct} / \mathrm{kWh}$ for North America. With annual running costs of $15 \%$ of investment, transmission costs to Europe amount to 6-8 $\mathrm{mills} / \mathrm{kWh}$, and those to North America to 4-6 mills/kWh. 
Table 11. Costs ( $\$$ \$) of electric transmission.

\begin{tabular}{|l|c|c|c|c|}
\hline \multicolumn{1}{|c|}{ Route } & I a & I b & II a & II b \\
\hline AC overhead at $400 \$ / \mathrm{m}$ & 360 & 580 & 760 & 1040 \\
DC overhead at 300 $\$ / \mathrm{m}$ & 210 & 240 & 240 & 480 \\
$\begin{array}{l}\text { DC sea cables } \\
1200-1600 \$ / \mathrm{m}\end{array}$ & $2340-3120$ & $2460-3280$ & $960-1280$ & $960-1280$ \\
$\begin{array}{l}\text { Converter stations } \\
\text { 10 GW at 20 } \$ / \mathrm{kW}\end{array}$ & 200 & 200 & 200 & 200 \\
\hline Total & $3110-3890$ & $3480-4300$ & $2160-2480$ & $2680-3000$ \\
\hline
\end{tabular}

\section{Cost of Energy Transportation--Hydrogen}

Investments and costs of energy transfers from each 5 GWstandard power scheme with hydrogen gas have been tentatively estimated based on reference data of future $\mathrm{H}_{2}$ electrolysis from La Roche [25] and General Electric [26], and of pipelines from the EURATOM publication [23] with control by EdF figures [30] (Table 12).

Table 12. Costs (M\$) for hydrogen transportation.

\begin{tabular}{|c|c|c|c|c|}
\hline Route & I a & $\mathrm{I} \mathrm{b}$ & II a & II $b$ \\
\hline $\mathrm{H}_{2}$ electrolysis & & & & \\
\hline $4-6 \mathrm{GW}$ at $30-50 \$ / \mathrm{kW}$ & $120-300$ & $120-300$ & $120-300$ & $120-300$ \\
\hline Pipelines on land & & & & \\
\hline $250-300 \$ / \mathrm{m}$ & $400-480$ & $560-680$ & $670-810$ & $1050-1260$ \\
\hline Sea pipelines & & & & \\
\hline $500-600 \$ / \mathrm{m}$ & $1000-1200$ & $1000-1200$ & $400-480$ & $400-480$ \\
\hline Total & $1520-1980$ & $1680-2180$ & $1190-1590$ & $1570-2040$ \\
\hline
\end{tabular}

No satisfactory reference data have been found for sea pipelines. Specific cost data of more than $1000 \$ / \mathrm{m}$ for $92 \mathrm{~cm}$ (36 inch) pipelines in the North sea oil field have not. been regarded as representative for future sea pipelines over many thousands of kilometers. Initial costs today in the North sea with pipelines of about $100 \mathrm{~km}$ only are certainly inflated by development and pioneer costs that will soon disappear when off-shore oil production and transport lines increase. A tentative assumption of twice the onland costs has been adopted.

Related to the power and energy units of the standard power scheme, the additional transport investments for $\mathrm{H}_{2}$ pipelines 
make up for $320-400 \$ / \mathrm{kW}$ or $4-5 \mathrm{ct} / \mathrm{kWh}$ to Europe, and $300-340$ $\$ / \mathrm{kW}$ or about $4 \mathrm{ct} / \mathrm{kWh}$ to North America. Conversion and transport costs to the European gas market amount to 6-7.5 mills/kwh input, and those to North America to about $5 \mathrm{mills} / \mathrm{kWh}$.

These estimates show that transmission costs of electric energy on EHV lines and those of hydrogen by gas pipelines are about equal. This is an interesting result since several authors have suggested that over distances of more than $400 \mathrm{~km}$ hydrogen transportation is much cheaper, down to one-tenth of the cost of electrical transmission [21,31]. Other authors fully support our result and have suggested that for distances of $1000 \mathrm{~km}$ or more, transportation costs with $\mathrm{EHV}$ or $\mathrm{H}_{2}$ gas pipelines are more or less equal $[30,32]$.

Reconversion of $\mathrm{H}_{2}$ into electrical energy via fuel cells needs an additional investment of $350-530 \mathrm{M} \$$ based on specific costs of $100 \$ / \mathrm{kW}$ [31]. Incremental generation costs in the fuel cell plant will be $1.5-2$ mills/kWh.

In hydrogen liquefaction, investments consist of the liquefaction plant roughly $600-900 \mathrm{M} \$(150 \$ / \mathrm{kW})$ for the standard glacier power scheme [33], and of two special tankers for liquid $\mathrm{H}_{2}$ transportation which might cost some $50 \mathrm{M} \$$. Operating and amortization costs of the Iiquefaction plant are 2.5-3 mills/kWh while transportation costs by tanker over some $4000 \mathrm{~km}$ are about 2-3 mills/kWh.

\section{EVALUATION AND INTEGRATION INTO A FUTURE GLOBAL ENERGY SYSTEM}

\section{General Evaluation}

Although cost estimates at this preliminary state of knowledge and planning include a considerable number of uncertainties, we have no reason to doubt that Greenland's glacier power, if at all feasible, is a very cheap source of energy. However, it is located far from potential energy markets, and its cost to the consumer will result from transportation and production costs, whatever mode of transportation is selected. This may render the Greenland energy economically less competitive than conventional power sources in the consumer regions of Europe or North America. The more so since only large-scale development is to be envisaged from the very beginning. An input of $5 \mathrm{GW}$ at one point of the existing transmission grid constructed to link a number of decentralized supply stations of the order of little more than 1 GW might cause additional distribution problems especially in Europe. North America has already several schemes of approximately the same power capacity as the standard scheme envisaged on Greenland.

In evaluating the Greenland energy, however, not only economic terms have to be considered. Hydropower resources still available today in the North Atlantic countries will most probably be fully developed by the year 2000. Development of 
Greenland's glacier power is an opportunity to continue traditional hydropower engineering and manufacturing for another half century, and to postpone the target date of inactivity of many substantial branches of industry. It would also continue to make profitable use of the advantages of hydropower in relation to conventional thermal or nuclear energy, namely:

- Longer lifetime of the power plant ( 80 years instead of 30 years, except machinery);

- Low production costs even under the severe maintenance conditions to be expected in the collector systems on the ice cap. Since production costs are predominantly determined by the annuities for external loans, and independent of rising fuel prices, they respond much more favorably to inflation and decrease to an almost negligible level after the amortization period;

- Independence from unstable and sometimes unreliable fuel supply conditions;

- The ecological advantage of using an inexhaustible, continuously renewed natural energy source without changing its quantity or quality, and with no harmful impacts such as air, water, or thermal pollution, radiation risks, or waste disposal.

\section{Options for Energy Transfer from Greenland}

Decision on the appropriate system for energy transfer from Greenland depends on cost criteria as well as on general considerations of the particular systems and of the market conditions. Figure 7 provides a survey of the options. They may be summarized in two scenarios: a pure electrical one, and a mixed electricalhydrogen one.

\section{Scenario A: A Pure Electrical System}

A combined DC-AC link of EHV overhead lines and sea cables seems feasible and promises some advantages as to transport loss and consumer costs if it is electrical energy that is wanted. This scenario deserves priority if sufficient storage reservoirs can be made available to warrant year-round full-load generation $(8000 \mathrm{~h}$ variant). It may also be adequate in cases of restricted reservoir facilities and rated generation periods of 6000 or $4500 \mathrm{~h}$ per year, if this period is more or less equally distributed over the year with intermittent full-load or even temporary part-load generation of say 12 or $16 \mathrm{~h}$ a day, at no extra cost for this peak load supply. (Peak load generation in a $8000 \mathrm{~h}$ plant would call for larger tunnel and penstock dimensions, and higher capacity installed in power station and transmission line at remarkable surplus cost which must be borne by higher earnings). 

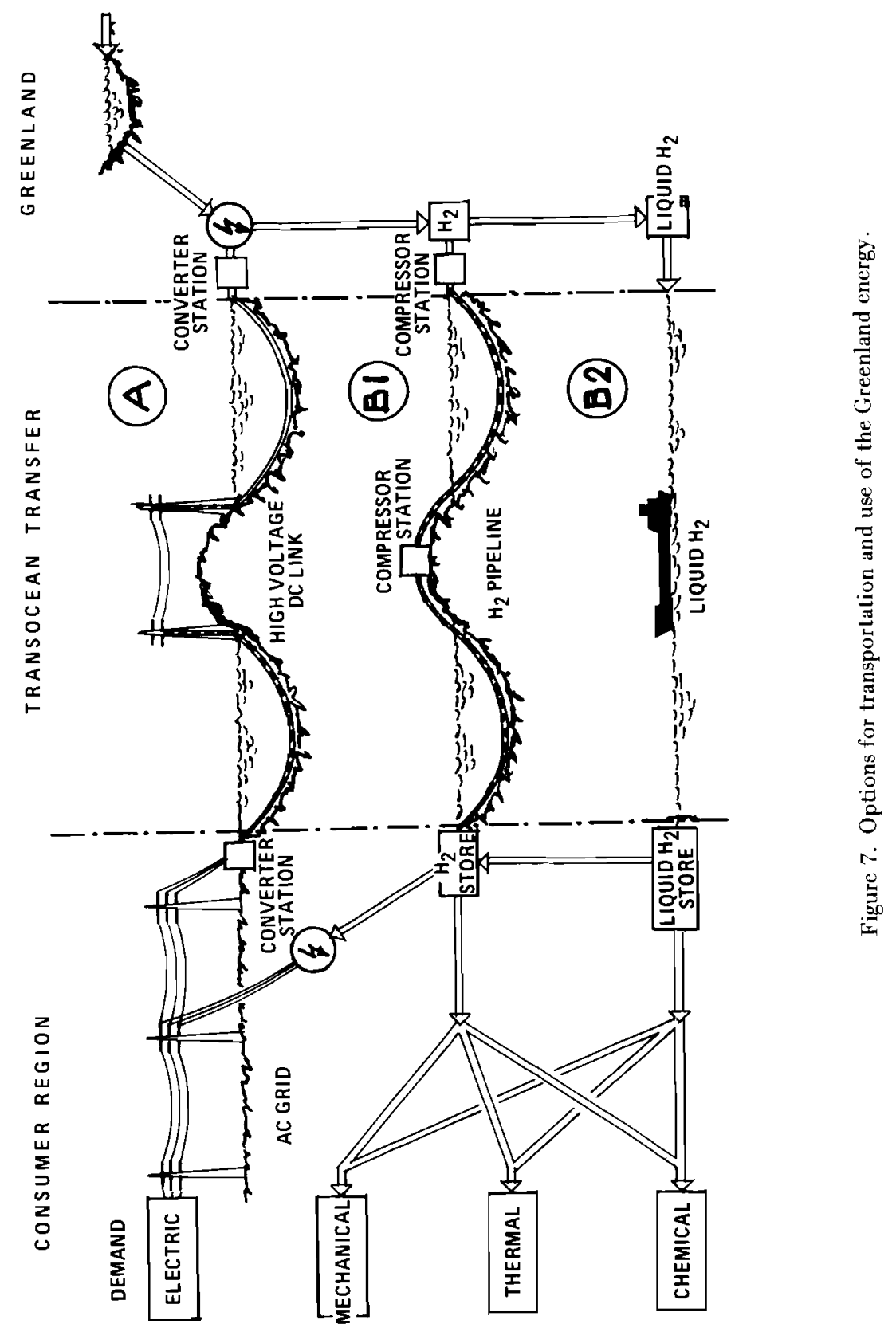


\section{Scenario B: A Mixed Electrical-Hydrogen System}

Electrical energy generated on Greenland goes directly into $\mathrm{H}_{2}$ electrolysis and is transferred to the consumer regions either by pipelines carrying $\mathrm{H}_{2}$ gas (Scenario $\mathrm{B} 1$ ) or by tankers carrying liquid $\mathrm{H}_{2}$ (Scenario $\mathrm{B}$ 2).

Scenario B 1 will reach its optimal economic value if, like scenario A, power generation with full load is warranted all year round. It will be competitive if markets for gas, thermal energy, or chemical processing exist in the consumer region, since reconversion into electrical energy either in gas turbines or in the boiler or a conventional thermal power station has a very low efficiency (35\%). Fuel cells with an expected higher efficiency of 65-70\% or hot-shot gas turbines would be more adequate but their technology is still to be developed and a large-scale application is not yet in sight [27].

Scenario B 2 suffers from higher conversion losses for liquefaction but might be an adequate solution for those power schemes in the east of Greenland where storage reservoirs are hardly to be found and power generation will be restricted to a maximum of perhaps 6 summer and fall months. This period is also the only time of the year when tankers will find access to the loading ports of liquid $\mathrm{H}_{2}$ near the power station and liquefaction plant. In the consumer region, liquid $\mathrm{H}_{2}$ can easily be stored for continuous sales. The scenario is handicapped by long idle periods--certainly not an ideal solution for large investments but still acceptable under the special conditions of some parts of Greenland.

\section{Energy Costs to the Consumer}

These depend on the final application of the energy from Greenland. If it should be electrical energy for every scenario, costs in US-mills per kWh available in the consumer region are assessed in a preliminary way as shown in Table 13.

Table 13 .

\begin{tabular}{|l|c|c|c|}
\hline & SC. A & Sc. B 1 & Sc. B 2 \\
\hline Generati, I on Greenland & $4.5-6.0$ & $4.5-6.0$ & $4.5-6.0$ \\
Conversion and transport & $4.0-8.0$ & $5.0-7.5$ & $4.5-6.0$ \\
Reconversion into electricity* & - & $1.5-2.0$ & $1.5-2.0$ \\
\hline Net cost, consumer region & $8.5-14.0$ & $11.0-15.5$ & $10.5-14.0$ \\
Energy losses*,* (8) & 198 & $38 \%$ & $44 \%$ \\
Equivalent surcharge & $1.5-2.5$ & $4.0-6.0$ & $4.5-6.0$ \\
\hline Cost of available energy & $10-16.5$ & $15-21.5$ & $15-20$ \\
\hline
\end{tabular}

*With fuel cells adopted.

** See "Power Application and Transfer" section. 
For thermal application, equivalent costs in US-\$/Gcal are as shown in Table 14 .

Table 14 .

\begin{tabular}{|l|c|c|c|}
\hline & SC. A & SC. B 1 & SC. B 2 \\
\hline Generation on Greenland & $5.25-7.0$ & $5.25-7.0$ & $5.25-7.0$ \\
Conversion \& transport & $4.75-9.5$ & $5.75-9.0$ & $5.25-7.0$ \\
\hline Net cost, consumer region & $10.0-16.5$ & $11.0-16.0$ & $10.5-14.0$ \\
Energy losses & 238 & 168 & 248 \\
Equivalent surcharge & $2.5-4.0$ & $2.0-2.5$ & $2.5-3.5$ \\
\hline Cost of available heat & $12.5-20.5$ & $13-18.5$ & $13-17.5$ \\
\hline
\end{tabular}

Tentative Development Model of Greenland's Glacier Power

Each scenario has its merits in production facilities, transmission advantages, and consumer market conditions. The market for large quantities of electrical energy will be found more easily in North America where also the transocean distance from Greenland is shorter. Both facts are in favor of scenario A. Most of the glacier power generated all year round in the schemes of Western Greenland will suit this option.

Existing oil and gas development in the North Sea by its bordering countries obviously favors scenario B 1. Glacier power in South Greenland may be regarded as a natural source of $\mathrm{H}_{2}$ gas supplies to Europe extending the fuel supply from the North sea beyond the date of their exhaustion.

Scenario B 2 is adequate for the less favored glacier power schemes of Eastern Greenland with intermittent operation periods and standstill during winter and springtime. Tanker transportation of liquid $\mathrm{H}_{2}$ can be to any port of the North Atlantic and even further south if market conditions warrant it.

These conditions, together with the adopted standard capacities of $10 \mathrm{GW}$ for a double-circuit EHV transmission link and of $5 \mathrm{GW}$ for an $\mathrm{H}_{2}$ gas Iine, induce a diversification of Greenland's glacial power according to the model illustrated in Table 15. This model must not be taken as final; it is just one particular development idea picked out of many possible ones. It may serve as an indicator, and is used as a basis for the considerations on investment, material, and other requirements that follow. 
Table 15. Tentative Development Model (75 GW).

\begin{tabular}{|c|c|c|c|c|}
\hline Scenario & $\begin{array}{c}\text { Supply } \\
\text { to }\end{array}$ & $\begin{array}{l}\text { Power } \\
\text { (GW) }\end{array}$ & $\begin{array}{l}\text { Transport } \\
\text { systems } \\
\text { per route }\end{array}$ & $\begin{array}{l}\text { Quantities supplied to } \\
\text { consumer regions per } \\
\text { year }\end{array}$ \\
\hline A & Europe & 10 & 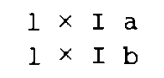 & 50-85 TWh electricity \\
\hline A & N. America & 30 & $\begin{array}{llll}2 \times & \text { II } & a \\
1 & \times & \text { II } & b\end{array}$ & 150-250 TWh el. \\
\hline B 1 & Europe & 15 & $\begin{array}{llll}2 \times I & a \\
1 \times & \times & b\end{array}$ & $25-43 \times 10^{9} \mathrm{Nm}^{3} \mathrm{H}_{2}$ gas \\
\hline B 1 & N. America & 10 & $\begin{array}{llll}l \times I I & a \\
l & \times \text { II } & b\end{array}$ & $17-43 \times 10^{9} \mathrm{Nm}^{3} \mathrm{H}_{2}$ gas \\
\hline B 2 & Atlantic & 10 & Tankers & $1.5-2.5$ Mt liquid $\mathrm{H}_{2}$ \\
\hline
\end{tabular}

\section{Integration Into a Global Energy System}

The parameters used by IIASA to evaluate an energy source and integrate it into the world economy are [35]:

- amounts of reserves and resources;

- requirements of land, material, equipment, labor force, and capital;

- global transport problems; and

- possible constraints.

Greenland's glacier power is now analyzed with regard to the first three parameters, while constraints are dealt with later.

\section{Reserves and Resources}

In IIASA's global energy program, future world energy demand of a population of $12 \times 10^{9}$ is estimated at 24-60 TW. Compared with this, an energy flow from Greenland of 50-90 GW has an insignificant share. In any decision on future energy options and strategies, hydropower is just of local or regional importance. In the near future, however, hydropower inputs are welcome, and in this time scale Greenland's glacier power could play a much more important role.

The Nuclear Research Institute at Jülich, FRG, recently published a survey of energy resources [36]. It includes an estimate of hydropower resources of the world based on assessments of the World Energy Conference and the regional economic 
commissions of the United Nations, with a breakdown by continents and by three levels of potential:

$$
\begin{aligned}
& \mathrm{E}_{\mathrm{o}^{\prime}} \text { theoretical potential derived from the total discharge } \\
& \text { of an area over the entire available head (comparable } \\
& \text { to the hypothetical reserves of the Mckelvey resources } \\
& \text { diagram); } \\
& \mathrm{E}_{\text {to' technically feasible potential, including non-economic }} \text { reserves; } \\
& \mathrm{E}_{t} \text { ' economically feasible potential (comparable to } \\
& \text { McKelvey's known and explored resources). }
\end{aligned}
$$

Table 16 expands the values offered by the Jülich Institute by adding the values for Greenland (all in TWh/a):

Table 16.

\begin{tabular}{|l|c|c|c|}
\hline \multicolumn{1}{|c|}{ Region } & $\mathrm{E}_{\mathrm{o}}$ & $\mathrm{E}_{\mathrm{to}}$ & $\mathrm{E}_{\mathrm{t}}$ \\
\hline Africa & 10,118 & 6832 & 3604 \\
Asia (incl. Asian USSR) & 16,486 & 7253 & 3192 \\
Europe (incl. European USSR) & 4,358 & 2450 & 953 \\
Latin American & 5,670 & 5054 & 3276 \\
North America & 6,150 & 2742 & 1409 \\
Austrialia and Oceania & 1,500 & 744 & 470 \\
\hline World & 44,282 & 25,075 & 12,904 \\
Greenland & 3,000 & $1000-1300$ & $460-800$ \\
\hline
\end{tabular}

\section{Land Requirements}

The land requirements of the glacier power schemes are modest even if one includes the land inundated by reservoirs on ice-free ground which in fact can be utilized like every natural water surface. Comparable hydropower schemes in the Alps have a permanent land requirement of $0.3-1 \mathrm{ha} / \mathrm{MW}$, an almost negligible land occupancy for construction facilities, and no land claims for fuel production. Reference data for other types of energy sources have been assessed by Grenon [38]:

- Solar power plant

- Coal-fired thermal plant

- Nuclear power plant
$3 \mathrm{ha} / \mathrm{MW}$ permanent

$0.5-2.5 \mathrm{ha} / \mathrm{MW}$ incl. strip mining over 25 years

$0.8-3.7 \mathrm{ha} / \mathrm{MW}$ incl. strip mining over 25 years. 


\section{Material Requirements}

The main items of construction material for the development of the Greenland energy and its transportation facilities are:

- cement and steel for the power stations,

- steel and aluminum for electric overhead lines,

- electric cables, and

- steel for gas pipelines.

Compared with these bulk quantities, requirements in other categories of the Kononov economic model [37] such as nonferrous metals and fabricated metal products, plastic, and synthetic materials, or wood and paper are unimportant.

Based on the "Tentative Development Model" outlined, each gigawatt of installed capacity requires the amounts of material shown in Table 17 .

Table 17.

\begin{tabular}{|c|c|c|c|c|}
\hline \multicolumn{2}{|l|}{ Material } & Power & EHV & Gas \\
\hline Cement & $(1000 \mathrm{t} / \mathrm{GW})$ & 25 & - & . \\
\hline $\begin{array}{l}\text { Steel, construction } \\
\text { mechanical and }\end{array}$ & $(1000 \mathrm{t} / \mathrm{GW})$ & 15 & 7 & 85 \\
\hline electrical equipm. & $(1000 \mathrm{t} / \mathrm{GW})$ & 20 & 1 & . \\
\hline Nonferrous metals & $(1000 \mathrm{t} / \mathrm{GW})$ & - & $4(\mathrm{Al})$ & - \\
\hline EHV cables & $(\mathrm{km} / \mathrm{GW})$ & - & 170 & - \\
\hline
\end{tabular}

Total requirements for the tentative model of nominally $75 \mathrm{GW}$ are Table 17's figures multiplied by 75. Over the construction period of 40-50 years, average annual demands are about 1.5-2 times the indicated figures. Individual development steps will of course differ more or less from the indicated amounts.

Other material parameters introduced by Grenon [37] are the weight of the station, and the total flow of material including fuel. The weight of the power station is understood as the total weight of elaborated materials used for the construction, in the case of hydropower this being cement and steel. The flow of material is defined as the quantities of raw material (but not of overburden) moved for fuel production in the case of a coal or nuclear plant, and that handled for the production of the heliostats in case of a solar power plant. Following these definitions, the material flow of a hydropower plant would be almost zero, since it needs no fuel and has no large material requirement other than concrete, earth and rock excavation, or 
dam fill, which have to be excluded for true comparison to the Grenon values. Hence two relevant values are given in Table 18 with the intention to add reference data for a glacier power station of $1 \mathrm{GW}$ to the Grenon table: values following the definitions, and in brackets higher values including the above mentioned main components of hydraulic engineering.

Table 18.

\begin{tabular}{|l|c|c|c|}
\hline 1 GW station & $\begin{array}{c}\text { Weight of } \\
\text { station } \\
\left(10^{6} \mathrm{t}\right)\end{array}$ & $\begin{array}{c}\text { Total flow } \\
\left(10^{6} \mathrm{t}\right)\end{array}$ & Conments \\
\hline Coal fired & $0.3-0.35$ & 50 & $2.5-75$ \\
Suclear (LWR) & $0.5-0.6$ & $\begin{array}{c}25 \text { years } \\
2 \text {-U shale } \\
25 \text { years } \\
5-7 \text { years }\end{array}$ \\
\hline Glacier power & $0.3-3$ & $0.5-1$ \\
\hline
\end{tabular}

\section{Equipment Requirements}

These are of two categories: mechanical and electrical equipment installed in the power stations and transmission facilities, and equipment and machinery used for construction.

- It has been pointed out that turbines, generators and other equipment of the glacier power stations are not different from those used today in large hydropower schemes all over the world, perhaps with some evolution but certainly with no innovations needed. Manufacturing of such equipment of the order of some $1.5 \mathrm{GW}$ per year over the construction period of 40-50 years will cause no change in the relevant manufacturing industry, and will be easily absorbed once the conventional consumer market ceases on completion of the on-going hydropower development in most of the North Atlantic countries. The extraordinary requirements for transmission facilities, however, will call for new production industries at least in the field of EHV sea cables which today are confined to lower voltage levels and to an order of $100 \mathrm{~km}$ and less. In this field, new technologies and a new industry have to be established with a production capacity of 200-300 km of EHV sea cable per year. Sea pipelines, on the other hand, exist already now with the deployment of off-shore gas and oil resources everywhere. A relevant industry will expand even without the Greenland option, and will most probably appreciate a market for their goods continuing beyond the limited time of the North sea boom. 
- New types of building equipment in large quantities will be needed for ice engineering, and part of this equipment will stay in permanent use for maintaining the collector canals on the ice cap. All other equipment for the construction of tunnels, penstocks and power stations, port and traffic facilities, and overhead EHV or pipelines will be met by the present rate of production. A few special vessels for sea cable or sea pipe laying will have no importance in any global production or trade model.

\section{Labor Force and Energy Requirements}

Hydropower development over the last 25 years has been characterized by a sharp decline of manpower on the construction sites due to the progress of energy-consuming mechanization. Reference data for Austrian hydropower stations show a drop from 500-800 man-months per installed megawatt to below 100 man-months/ megawatt, although no pronounced correlation of manpower with installed capacity was evident. A labor force of 2000-2500 workers including the planning, assembling and control staff would seem a natural limit for a large construction site. With two schemes under construction at a time, a labor force of 4000-5000 people will be needed continuously for implementation of the Greenland project. Manpower for each standard scheme with 5 to 6 years construction time amounts to 100-150,000 manmonths--equivalent to only 25-30 man-months/megawatt.

The less manpower, the more mechanization is needed. Recent experience at various hydropower construction sites is that the peak demand of construction equipment in mechanized horsepower is numerically equal to, or a bit less than, the total number of man-months accumulated at this site. For hydropower plants smaller than $100 \mathrm{MW}$, maximum demand may go up to twice the number of manmonths. Hence construction equipment with a peak motor power of 100-120,000 hp (75-90 MW) will have to be installed at each site while the average demand will be 65-80,000 hp (45-60 MW). Fueldriven and electrical equipment will have approximately equal shares. The total requirement of construction equipment for the Greenland project with two overlapping construction sites running at a time amounts to $150-180,000 \mathrm{hp}$ (112-135 MW).

Energy consumption of the Greenland construction sites will be higher than that of conventional hydropower sites, due to the arctic climate causing a considerable heating demand all year round. Electric energy consumption may amount to $20,000 \mathrm{kWh}$ per capita and year totaliling at 200-300 GWh for each power scheme, not including energy extras which might be needed for artificial heating in ice engineering. Fuel driven equipment will consume $20-25 \times 10^{6}$ liters $(125-160,000$ barrels) of fuel for the construction of each standard glacier power scheme. 


\section{Capital Requirements}

The "Energy Impact Model" developed by IIASA in cooperation with the Siberian Power Institute of the USSR Academy of Science works with direct as well as indirect investment requirements. The categories of this model are the basis for the following breakdown of approximate investment requirements of the 75 GW Tentative Development Model of Greenland energy (Table 19).

Table 19.

\begin{tabular}{|c|c|c|c|c|c|}
\hline & \multicolumn{2}{|c|}{$\begin{array}{l}\text { Investment totals } \\
\text { direct indirect } \\
\left(10^{9} \$\right) \quad\left(10^{9} \$\right)\end{array}$} & \multicolumn{2}{|c|}{$\begin{array}{c}\text { Annual } \\
\text { Investment Rates }\end{array}$} & $\begin{array}{l}\text { Period } \\
\text { (years) }\end{array}$ \\
\hline Power schemes & 21.5 & - & 480 & - & $45(6-50)$ \\
\hline $\mathrm{H}_{2}$ electrolysis & 2.0 & - & 50 & - & $40(11-50)$ \\
\hline $\mathrm{H}_{2}$ liquefaction & 1.5 & - & 50 & - & $30(21-50)$ \\
\hline EHV transmission & 15.0 & - & 430 & - & $35(6-40)$ \\
\hline New cable industry & - & 0.5 & - & 100 & $5(1-5)$ \\
\hline Gas pipelines & 8.5 & - & 270 & - & $30(11-40)$ \\
\hline Liquid $\mathrm{H}_{2}$ tankers & - & 0.1 & - & 20 & $5(21-25)$ \\
\hline Total & 48.5 & 0.6 & $1280 \mathrm{max}$ & . & $20(21-40)$ \\
\hline
\end{tabular}

\section{Global Transportation Problems}

Transportation of Greenland energy to the consumer regions over distances of $4000 \mathrm{~km}$ poses virtually the same problem as other energy options envisaged for the future, e.g. large-scale solar power developments in the sahel region or a nuclear power pack (the "energy island") in the Pacific or any other remote place [39]. However, there is a big difference in the order of magnitude which is some $75 \mathrm{GW}$ in the case of Greenland versus several terawatts of the energy island. Even the present flow of oil from the Middle East of $1.7 \mathrm{TW}$ is much higher than the future power flow from Greenland.

Transportation of construction material and equipment from production facilities in Europe or North America to Greenland will influence construction costs, but an additional volume of 150-250,000 $t$ a year will pose no problem on world traffic. The same is true for placing orders on perhaps four medium size special tankers for the transport of liquid $\mathrm{H}_{2}$. A minor problem could arise from the requirement of aircraft for dispersing darkening substances on large ice areas in order to accelerate melting. 


\section{Evaluation of Constraints}

The analysis of possible constraints affecting the development of Greenland's glacier power follows six categories which have been established by IIASA for the evaluation of a new energy source [35].

- Market penetration is no problem since the Greenland project just extends conventional hydropower over another half century in supplying established markets for electricity or gas in developed countries which are in need of energy imports.

- No new standards have to be fixed since most technologies to be applied are well advanced, and only a few categories such as ice engineering or sea cables need further steps of evolution.

- No change in infrastructure will take place except the establishment of settlements and traffic facilities on Greenland. Both electricity and gas dispose of an established industrial infrastructure with a considerable rate of expansion.

- Capital constraints might arise if the Greenland energy had to be developed by Greenland or Denmark on their own, but if a joint multilateral development took place, a capital requirement of the order of $10^{9}$ us-\$ per year is no limiting factor. The disadvantage of higher specific investment needs of some $600 \$ / \mathrm{kW}$ including transmission is compensated by low operating costs, even with extraordinary costs for maintenance, and by the lack of any fuel expenses.

- Ecological impacts have to be studied carefully but on a first preliminary judgment no impacts of global importance should be expected from the change of the glacier regime by the energy development. It has been stated that perhaps $100-200 \mathrm{~km}^{3}$ of ice mass will be tapped annually in excess of the present conditions by increased melting. This is not only negligible against the total volume of Greenland's ice mass of $2,600,000 \mathrm{~km}^{3}$ but also it is within the limits of natural variations of accumulation and ablation, estimated by different authors at between +295 and $-84 \mathrm{~km}^{3}$ per year [36]. Local impacts in the development area of Greenland may emerge from additional glacier ablation accumulating over 100 years to a total of $50 \mathrm{~m}$ out of a mean ice thickness of $1500 \mathrm{~m}$, and from an additional supply of warmer water from the reservoirs to the surrounding ocean of the order of $100 \mathrm{GW}$ as against a heat transfer by the Gulf Stream of $660 \mathrm{TW}$. The water table of the oceans will react only insignificantly to the additional melting discharge by a cumulative rise of $3-4 \mathrm{~cm}$ over 100 years.

- Risks exist with regard to the technical and economic feasibility and the performance of the collector system 
on ice, but hardly with regard to the human environment. Glacier power has no emissions, no waste, no hazards-especially in a thinly populated area like Greenland where even such low probability risks as a dam failure, or bursting of an ice dam or channel will have insignificant detrimental effects. Nor could the failure of a sea pipeline carrying pure hydrogen have polluting or poisoning impacts. Local impacts around the electrodes of the DC sea cable terminal can be met by adequate protective devices. Potential impacts on fish and limnology in the fjords where turbine outlets discharge warmer water throughout the year can be advantageous as well as disadvantageous and have to be studied.

Summarizing the above considerations, one should not expect any serious constraints of an economic or ecological nature which might prohibit the development of the Greenland energy if it proves to be technically feasible.

\section{FURTHER STEPS TOWARDS A DEVELOPMENT OF THE GREENLAND ENERGY}

It is hoped this study will serve to create a broader interest in more profound studies on Greenland's glacier power by the governments or energy administrations of the North Atlantic border states concerned by and involved in the development, by the Danish authorities responsible for the administration of Greenland, and by international organizations such as the United Nations in its Center of Natural Resources, Energy and Transport (CNRET) of the Economic and Social Council, or UNESCO and WMO.

The study program could consist of an intensified collecting of basic scientific data, and a more practicability-oriented test and investigation program including the new technologies to be developed. A tentative--certainly not complete--list of topics for a study program is outlined here.

\section{Basic Information and Data Collection}

- Collection and study of ERTS photos of South Greenland for an overall survey of snow cover and ice conditions in all seasons.

- Aerial photography of the ice cap and surrounding mountain ridges down to the ocean, south of $72^{\circ} \mathrm{N}$ in the west and of $690 \mathrm{~N}$ in the east.

- Topographic surveying of border zones of the ice cap and surrounding mountain ridges in selected areas, in specific test areas.

- Establishment of climatological stations (temperatures of air, snow, ice, and water; wind; precipitation; sunshine and radiation; albedo) on the ice cap up to $2000 \mathrm{~m}$. 
- Observation of snow, firn, and ice behavior in the soaking and ablation zones; data collection for estimating water yields.

- Study of the ecological impacts of increased melting with regard to the glacier regime, global weather conditions, ocean currents, ice drift and pack ice, water and air temperatures and local climate; data collection for quantifying such impacts.

- Identification of climatic consequences of an albedo change" by the artificial darkening of large ice areas.

- Exploration of permafrost occurrence in areas where construction activity might be expected.

- Selection of an easily accessible test area where glacier power development seems most promising, and intensified observations there.

\section{Preparatory Technical Investigations and Tests}

Topics for the technical study and testing program prior to the planning and design phase of the first power development are:

- Investigation of the melting process and of appropriate methods to collect melting waters and to keep them from refreezing.

- Testing of heat-absorbing substances and materials such as dark sand, fly ash, PVC lining, and their accelerating effect on melting, and an estimate of the technical and economic feasibility of their large-scale application.

- Investigation of ice properties in view of its proposed use as a construction material for collector canals or reservoirs; tests of watertightness, roughness, and stability.

- Construction of a prototype collector canal on the ice cap, comparative tests of construction methods and equipment such as excavation by bulldozers or snowmills, and forced melting by motor exhaust, electric resistance heating, or nuclear waste containers.

- Observation of the behavior of the prototype canal, its resistivity to ice movements, an estimate of the amount of maintenance work, a study of maintenance equipment and methods.

- Test borings in permafrost rock, observation of ground temperatures around the borehole with and without water flow in various seasons. 
- Testing of resistance of building materials and tunnel linings (concrete, steel and others) against permafrost.

- Exploration of favorable coastal sites for large-scale power stations and industrial accessories, with acceptabl, access from the sea and to the glacier region.

- Exploration of reservoir sites in the mountain valleys bordering the ice cap, and on ice where other sites do not exist.

- Calculation of flood wave risks stemming from failures of main collectors or reservoirs in the ice.

- Research on the development of hydraulic turbines for high head, flow, and capacity.

- Intensified research on EHV sea cables, and a study of methods for crossing ocean channels of great depths down to $1000 \mathrm{~m}$ and more.

- Intensified and specified research on the components of the hydrogen scenario.

- Study of fresh water supply from Greenland to regions of high water demand, prototype tests of long-distance transportation of large quantities of pure fresh water available from the turbine discharge.

A comprehensive study program like this will depend on the close interdisciplinary cooperation of experts of glaciology, physics, civil engineering, mechanics, electric and mechanical manufacturing, transportation, and others. Some tests might be done outside Greenland under similar but less severe climatic and environmental conditions such as the glaciers of Alaska or Norway.

With satisfactory and promising results from this study program, then planning and design can start. Decision on the construction of the first power scheme must be based on evidence of the technical and economic feasibility of the entire project. 


\section{REFERENCES}

[1] Barüske, H., Grönland - Grösste Insel der Erde (Greenland the Largest Island on Earth), Series "Die Welt von heute", Safari, Berlin, 1968.

[2] Lange, R., Zur Erwärmung Grönlands und der atlantischen Arktis (Calefaction of Greenland and the Atlantic Arctics), Ann. Meteorol., 1959, quoted in [5].

[3] Kollbrunner, C., and H. Stauber, Gletscherkraftwerke in Grönland (Glacier Power Schemes in Greenland), Publ. no. 24 of the Institute of Engineering Research, Rodio, Switzerland, 1972; and Unerschöpfliche saubere Wasserund Energiequelzen (Inexhaustible and clean Sources of Water and Energy), Publ. no. 25, The Institute of Engineering Research, Rodio, Switzerland, 1973.

[4] Stauber, H., Anlage von Schmelzwasserkraftwerken in ewigen Eis (Development of hydro-electric schemes in perennial ice), Austrian Patent no. 252131 of February 1967. Similar patents have been awarded in Norway 1966, Switzerland 1967, Canada and Iceland (1968), USA and FRG (1969), and Denmark.

[5] Putnius, P., The Climate of Greenland, World Survey of Climatology vol. 14, Polar Regions, Elsevier, Amsterdam, 1970 .

[6] Tables of Temperature, Humidity and Precipitation for the World, Part 1, Meteorological office, London, 1958.

[7] UNESCO - WMO, Climatologic Atlas of Europe, Budapest, 1972.

[8] The Times Atlas of the World, The Times, London, 1973.

[9] Löf, O.G., J.A. Duffie, and C.O. Smith, World Distribution of Solar Radiation, Rep. no. 21, The University of Wisconsin, Wisconsin, 1966.

[10] Loewe, F., Das Klima des grönländischen Inlandeises (The Climate of Greenland's Inland Ice), Handbuch der Klimatologie, 1935, quoted in [5].

[11] Gerdel, R.W., A Climatological Study of the Greenland Ice Shield, Physical Geography of Greenland Series, Folia Geographica Danica, Copenhagen, 1961, quoted in [5].

[12] Ambach, W., Investigations of the Heat Balance in the Area of Ablation on the Greenland Ice Cap, Physical Geography of Greenland Series, Folia Geographica Danica, Copenhagen, 1961, quoted in [5].

[13] Golubev, G., Gidrologija lednikov (Hydrology of Glaciers), Gidrometeoizdat, Leningrad, 1976. 
[14] Sellers, w.D., Physical Climatology, University of Chicago Press, Chicago, 1972 .

[15] Arnold, K., An Investigation into Methods of Accelerating the Melting of Ice and Snow by Artificial Dusting, Geology of the Arctic, University of Toronto Press, Toronto, 1961 .

[16] Häfeli, R., Die internationale glaziologische Grönlandexpedition 1957 bis 1960 - E.G.I.G. (The International Glaciological Expedition to Greenland 1957-1960), Schweizerische Bauzeitung, no. 29, 1959.

[17] Benson, C.S., Stratigraphic Studies in the Snow and Firn of the Greenland Ice Sheet, Physical Geography of Greenzand, Golia Geographica Danica, Copenhagen, 1961.

[18] Kollbrunner, C. and A. Von Rotz, Eisbauarbeiten und Energiestoff bei Ausführung von Gletscherkraftwerken in Grönland (Ice Engineering and Construction Materials for Glacier Power Schemes in Greenland), Publ. no. 27, The Institute of Engineering Research in Rodio, Switzerland, 1973.

[19] Stimmer, H., Aspekte elektrischer Hochleistungs übertragung (Aspects of Electrical High Power Transmission), Proceedings of a joint seminar of the rechnical University Vienna and the International Institute for Applied Systems Analysis, Laxenburg, Austria, in the press.

[20] Engström, L., Refining Copper with HVDC, IEEE Spectrum, no. 12,1975 .

[21] Weyss, N., Wasserstoff - Informationen zum $\mathrm{H}_{2}$-Konzept (Information on the Hydrogen Economy), Energie, nos. 1 and 2, 1974, and Separatum BBC, Baden, Switzerland.

[22] Gregory, D.P., and J. Wurm, Production and Distribution of Hydrogen as a Universal Fuel, $7^{t h}$ Intersociety Energy Conversion Conference San Diego, American Chemical Society, washington, 1972.

[23] Beghi, G., et al., Hydrogen, oxygen and natural gas by pipelines, publ. EUR-5103.e of EURATOM, CCR, Ispra.

[24] Sammarco, M., and G. Bonfiglioli, Gas sealines for supplying the Western European market, Paper $\mathbf{R} 20$ given at the ECE Seminar on Problems of Sea Pipelines, Florence, 1976 .

[25] La Roche, U., Modern Technology Electrolysis for Power Application, Appendix F in W. Häfele and W. Sassin, Applications of Nuclear Power Other Than for Electricity Generation, RR-75-40, International Institute for Applied Systems Analysis, Laxenburg, Austria, 1975. 
[26] General Electric, SPE Water Electrolysis Technology Development for Bulk Energy Storage Systems, Report prepared for the Brookhaven National Laboratory, N.Y., USA, 1975.

[27] Weyss, N., Brennstoffzellen (Fuel Cells), Techniken der Zukunft no. 6, 1973.

[28] De Beni, G., Hydrogen and Other Energy Vectors, Appendix B in W. Häfele and W. Sassin, Applications of Nuclear Power Other Than for Electricity Generation, RR-75-40, International Institute for Applied Systems Analysis, Laxenburg, Austria, 1975.

[29] Barnett, H.J., The Bauxite Cartel in the New International Economic Order, Internal Paper, International Institute for Applied Systems Analysis, Laxenburg, Austria, 1976.

[30] Electricité de France, Estimation du coût du transport pour deux structures énergétiques: hydrogène électricité (Transport Cost Estimates for Two Energy Systems: Hydrogen and Electricity), Internal Report, Electricité de France, Paris, France, 1973.

[31] Winsche, W., K. Hofmann and F. Salzano, Economics of Hydrogen Fuel for Transportation, $7^{\text {th }}$ Intersociety Energy Conversion Conference, San Diego, American Chemical Society, Washington, 1972 .

[32] Brüderlin, H., Energiespeicherung und -transport (Storage and Transportation of Energy); unpublished lecture to the Reactor Conference, Dusseldorf, 1976.

[33] Linde Division of Union Carbide, Survey Study of the Efficiency and Economics of Hydrogen Liquefaction, NASA CR-132631, Houston, Texas, USA, 1975.

[34] UCPTE, (Union for the Coordination of Production and Transport of Electric Energy), Annual Report, UCPTE, Laufenburg, Switzerland, 1974-75.

[35] Häfele, W. and W. Sassin, Zukünftige Energieversorgung optionen und Strategien (Future Energy Supply - Options and Strategies), Series Bergbau-Rohstoffe-Energie, No. 14, Verlag Glückauf, Essen, 1976.

[36] Energiequezzen für morgen (Energy Resources for the Future), Publ. ASA-ZE/03/75 of Arbeitsgemeinschaft für Grossforschungseinrichtungen, Jülich, 1975.

[37] Kononov, Y., Modeling of the Influence of Energy Development on Different Branches of the National Economy, RR-7611, International Institute for Applied Systems Analysis, Laxenburg, Austria, 1976. 
[38] Grenon, M., Coal - Resources and Constraints, in W. Häfele, et al., Second Status Report of the IIASA Project on Energy Systems, RR-76-1, International Institute for Applied Systems Analysis, Laxenburg, Austria, 1976.

[39] Marchetti, C., Geoengineering and the Energy Island, in W. Häfele et al., Second Status Report of the IIASA Project on Energy Systems, RR-76-1, International Institute for Applied Systems Analysis, Laxenburg, Austria, 1976. 
Fusion and Fast Breeder Reactors. W. Häfele, J.P. Holdren, G. Kessler, G.L. Kulcinski. (rr77-008) \$18.80/AS340.

A Systems Approach to Development Planning of the Fuel Power Industry of a Planned-Fconomy Country. L.S. Belyaev. (rr76-006)\$1.50/AS30.

On Hydrogen and Energy Systems. C. Marchetti. (rr76-007) \$2.00/AS40. (MICROFICHE ONLY)

Frobability Forecasts: A Survey of National Weather Service Forecasters. A.H. Murphy, R.L. winkler. (rr75-009) \$1.00/AS20.

Transport and Storage of Energy. C. Marchetti. (rr75-038) \$2.50/AS45.

Power Plant Siting: A Paretian Environmental Approach. J.G. Gros. (rr75-044) \$1.00/AS20.

Hydrogen: Mechanisms and Strategies of Market Fenetration. A.S. Manne, C. Marchetti. (rr74-004) \$2.00/AS40. (MICROFICHE ONLY)

Methods of Systems Analysis for Long-Term Energy Development. Yu.D. Kononov, editor. (cp77-002) $\$ 2.50 /$ AS 45 .

Air Pollution Dispersion Models as used in Poland in Regional Development Planning. J. Pruchnicki. (rm77-005) \$1.50/AS30.

Solar Energy Task Progress Report for 1975/76: Evaluation of Solar Energy Options. C.R. Bell. (rm77-020) \$2.50/AS45.

Systems Aspects of Large-Scale Solar Energy Conversion. J.M. Weingart. (rm77-023) $\$ 2.50 /$ AS45. 
Application of a Simple Multiattribute Rating Technique to Evaluation of Nuclear Waste Disposal Sites: A Demonstration. H.J. Otway, W. Edwards. (rm77-031) \$1.50/AS30.

Energy, Entropy, and Information. J. Thoma. ( rm77-032) \$1.50/AS30.

Further Studies of the Impact of Waste Heat Release on Simulated Global Climate: Part I.J. Williams, G. Krömer, A. Gilchrist. (rm77-015) $\$ 1.50 / \operatorname{AS} 30$.

Further Studies of the Impact of Waste Heat Release on Simulated Global Climate: Part II. J. Williams, G. Kromer, A. Gilchrist. (rm77-034) $\$ 2.50 /$ AS 45 .

On Geoengineering and the $\mathrm{CO}_{2}$ Problem. C. Marchetti. (rm76-017) \$1.00/AS20.

Regional Air Pollution Impact: A Dispersion Methodology Developed and Applied to Energy Systems. R.L. Dennis. (rm76-022) \$2.50/AS45.

Evaluation of Health Effects from Sulfur Dioxide Emissions for A Reference Coal-Fired Power Plant. W.A. Buehring, R.L. Dennis, A. Hölzl. (rm76-023) $\$ 3.50 /$ AS60.

Social Aspects of the Nuclear Power Controversy. H. Nowotny. (rm76-033) \$2.50/AS45.

The Impact of Waste Heat Release on Simulated Global Climate. A.H. Murphy, A. Gilchrist, W. Hafele, G. Krömer, J. Williams. (rm76-079) $\$ 1.50 /$ AS 30 .

The Determinants of Attitude Formation: An Application to Nuclear Power. H.J. Otway, M. Fishbein. $(r m 76-080) \$ 1.50 / \operatorname{AS} 30$.

Please cite publication number when making an order. See inside back cover for order information. 